\title{
Pero se escondíamos como las ratas: syncretism in the reflexive paradigm in Spanish and Catalan
}

\author{
Carlota de Benito Moreno \\ University of Zürich \\ carlota.debenitomoreno@uzh.ch
}

Received: 20-05-2014

Accepted: 07-07-2014

\begin{abstract}
In this paper I provide a description of the reflexive syncretism found in some Spanish and Catalan neighbouring varieties. In these varieties, the $3^{\text {rd }}$ person reflexive pronoun se can also appear with $1^{\text {st }}$ person plural and $2^{\text {nd }}$ person plural verbs. With dialectal data from the Audible and Spoken Corpus of Rural Spanish (COSER), the Linguistic Atlas of the Iberian Peninsula (ALPI) and from works of other scholars I analyse the distribution of the syncretism in order to establish what person (the $1^{\text {st }}$ plural or the $2^{\text {nd }}$ plural) it affected first. I also analyse this syncretism in other Romance languages, in order to see if the person hierarchies previously proposed in the literature are confirmed by these varieties.
\end{abstract}

Key words: reflexive pronouns; syncretism; Spanish; Catalan; typological hierarchies.

\section{Table of Contents}

1. Introduction

2. Reflexive systems across the world
4. The reflexive paradigm in the

Valencian Country and Murcia

5. Conclusion

3. Reflexive systems in Romance 


\section{Introduction}

In September 2013, during the last large COSER interviews campaign, ${ }^{1}$ a team of 23 linguists did dialectology fieldwork in the Spanish provinces of Castelló, València, Alacant and Murcia. At the very first interview I took part in, the speaker showed a regular use of the reflexive pronoun se not only in the $3^{\text {rd }}$ person, but also in the $1^{\text {st }}$ and $2^{\text {nd }}$ person plural.

Lucena del Cid, Castellón, COSER 1308

$(\text { Spanish })^{2}$

El novio le decía al padre:

The groom him.DAT said to.the father

'The groom used to tell the father:'

"Mira, hamos pensao de casarse, ¿a usté qué le parece?" look have.1PL thought.PTCP of marry.INF-3.REFL to you what him.DAT seems "'Look, we want to get married, what do you think?"”

"Ay, pues mira, a mí me parece, si vosotros se queréis, oh well look to me.OBL me.DAT seems if you.PL 3.REFL love.2PL “'Oh, well, I think, if you love each other,'

pues me parece muy bien que se caséis"

well me.DAT seems very well that 3.REFL marry.2PL

'then I think you should get married"'

During the following days, we found this usage in several other villages, making it clear that it was not an isolated phenomenon, but a regular one in the area. In this work I will present a first approach (the first one, to my knowledge) to this phenomenon, analysing both data from the COSER interviews and the ALPI. In section 2 I will relate the phenomenon to the typological difference between functionally streamlined and strategically streamlined reflexive paradigms (Faltz 1985). In section 3 I will present a brief summary of parallel phenomena in other Romance languages. Section 4 will be devoted to describing and analysing the phenomenon in Eastern Spanish and in Catalan, in order to propose a historical evolution across the different verbal persons. Lastly, I will provide some conclusions in section 5.

\section{Reflexive systems across the world}

In Faltz's (1985: 118-119) typological survey of reflexive systems, he notices that true pronominal reflexive systems may occur in two different forms in the languages of the

I would like to thank Albert Wall, Claudi Meneghin, Marco Tamburelli, Debbie Bryce, David Heap and José Luís Forneiro for kindly helping me by providing me with relevant data and data sources and answering my questions about them; and Álvaro Octavio de Toledo, Inés Fernández-Ordóñez, Claudi Meneghin, María Pilar Perea, Anna Pineda and two anonymous reviewers for their insightful comments to previous versions of this paper. Of course, any remaining errors and misconceptions are mine.

COSER stands for Corpus Oral y Sonoro del Español rural (Audible and Spoken Corpus of Rural Spanish), directed by Inés Fernández-Ordóñez, see section 4.

Unless otherwise indicated, I use Leipzig glossing rules and abbreviations when glossing the examples. 
world. ${ }^{3}$ On the one hand, some languages only have a reflexive pronoun in the $3^{\text {rd }}$ person, using the regular pronouns for every other person. Standard Spanish is a good example: the $3^{\text {rd }}$ person (both singular and plural) reflexive marker, se, contrasts with the $3^{\text {rd }}$ person non-reflexive pronouns $(l e(s), l a(s), l o(s))$, while in the $1^{\text {st }}$ and $2^{\text {nd }}$ persons (singular and plural) the reflexive and the non-reflexive pronouns are the same (me, te, nos, os).
a. $\left[\mathrm{Bea}_{\mathrm{i}}\right]$ Ana la $\mathrm{i}_{\mathrm{i}} \quad$ vio
[Bea] Ana her.ACC saw.3sG
'[Bea $\left.{ }_{i}\right]$ Ana saw her ${ }_{i}$ '
b. $\mathrm{Ana}_{\mathrm{i}} \mathrm{Se}_{\mathrm{i}}$ vio
Ana 3.REFL saw.3SG
'Ana saw herself'
a. [a mín $i_{i}$ Ana me $e_{i}$ vio
[to me] Ana me.ACC saw.3sG
' $\left[\mathrm{me}_{\mathrm{i}}\right]$ Ana saw $\mathrm{me}_{\mathrm{i}}$ '
b. $\mathrm{Yo}_{\mathrm{i}} \mathrm{me}_{\mathrm{i}}$ vi
I me.ACC saw.1sG
'I saw myself'

(Spanish)

(Spanish)

Faltz considers these systems to be "functionally streamlined", since the reflexive form is found in the only context where ambiguity may be caused by the use of a non-distinct marker, since both $1^{\text {st }}$ and $2^{\text {nd }}$ persons have unequivocal reference.

The other typological possibility is to have a system with a distinctively reflexive marker in every person. Russian is a good example of this, with the reflexive form sebja used in every person. He considers these systems to be "strategically streamlined", since they mark co-reference in every case, regardless of person.

videt' sebja
ja vižu sebja
ty videš sebja
on/ona/ono videt sebja
my videm sebja
vy videte sebja
oni vidjat sebja
'to see oneself'
'I see myself'
'You see yourself'
'He/she/it sees himself/herself/itself'
'We see ourselves'
'You see yourselves'
'They see themselves'

(Spanish)

(Spanish)

Faltz (1985: 120) finds just a few examples of reflexive systems that cannot be classified within these two types, that is to say, languages where the reflexive marker is used in more persons than only the third, but not in all. He hypothesizes that these are intermediate stages of the process whereby a functionally streamlined system turns into a strategically streamlined one. Although he admits to having little evidence for this, he also proposes that, in this extension, the reflexive marker spreads first to the $2^{\text {nd }}$ person and only afterwards to the $1^{\text {st }}$.

This typological prediction has been challenged by Puddu (2010). In a very interesting work, she looks at a larger sample of languages with "intermediate" reflexive

$3 \quad$ Faltz opposes true pronominal reflexives to fused adjunct reflexives such as English myself, yourself, etc., which, albeit pronouns, still show their origin of pronominal head + noun. For a more detailed description of the formal possibilities of reflexive systems, cf. Faltz (1985: chapter II). 
paradigms and shows that Faltz's hierarchy is not supported by evidence. According to her, although it is true that reflexive forms normally spread from the $3^{\text {rd }}$ person singular to others, it is not always the case that this extension always affects the $2^{\text {nd }}$ person before the $1^{\text {st }}$. In Javanese Ngoko (Trans-New Guinea), for example, the reflexive marker spread first to the $1^{\text {st }}$ person plural (Cole, Hermon, Chonghyuck, Chang-Yong, \& Yaping 2003, apud Puddu 2010).

On the other hand, she claims that, from a diachronic point of view, when reflexives spread from the $3^{\text {rd }}$ person to the others, they show up first in the plural and only later in the singular, whereas the opposite situation is unattested. ${ }^{4}$

On the basis of data from Italian dialects, Benincà \& Poletto (2005) propose that in the evolution from one reflexive system to the other, Romance languages follow the hierarchy in (5)..$^{5}$ As can be seen, this hierarchy is also in contradiction with Faltz's proposal.

$$
3^{\text {rd }} / 6^{\text {th }}>4^{\text {th }}>5^{\text {th }}>2^{\text {nd }}>\left(1^{\text {st }}\right)
$$

\section{Reflexive systems in Romance}

Although all the major Romance languages have a functionally streamlined reflexive system in their respective standards, as Latin itself did, the strategically streamlined paradigm is not unknown in the family. For starters, Surselvan (Rhaeto-Romance) shows a fully strategically streamlined reflexive paradigm in which all persons are syncretic with the $3^{\text {rd }}: s e-\left(\right.$ Stimm 1973, Meyer-Lübke 1906, Meneghin 2008). ${ }^{6}$

$\begin{array}{ll}\text { selavar } & \text { 'to wash oneself' (Stimm 1973) } \\ \text { jeu selavel } & \text { 'I wash myself' } \\ \text { ti selavas } & \text { 'You wash yourself' } \\ \text { el, ella selava } & \text { 'He, she washes himself, herself' } \\ \text { nus selavein } & \text { 'We wash ourselves' } \\ \text { vus selaveis } & \text { 'You wash yourselves' } \\ \text { els, ellas selavan } & \text { 'They wash themselves' }\end{array}$

(Surselvan)

Some other Rhaeto-Romanic and Northern Italian varieties also present a fully formed strategically streamlined reflexive paradigm. According to Meneghin (2008), that is the case in Sutsilvan (Romansh/Rhaeto-Romance), Bergamasque and Bressan (East Lombard) and the variety spoken in Collina d'Oro (West-Lombard). ${ }^{7}$

$4 \quad$ From now on, I will use numbers from 1 to 6 to refer to the verbal persons, so as to keep clear the difference between singular and plural persons. Unless otherwise specified and for the ease of explanation, $3^{\text {rd }}$ person will also be meant to include the $6^{\text {th }}$, since they are syncretic in all the varieties mentioned in this paper.

5 Although Benincà \& Poletto (2005) do not specify the role of the $6^{\text {th }}$ person in their proposal, it is clear from their paper that it aligns with the $3^{\text {rd }}$.

6 As can be seen in (6), in Surselvan the reflexive marker is not a pronoun anymore, but a verbal prefix. According to Faltz (1985), pronominal systems are one of the possible diachronic sources of verbal reflexive systems, as undoubtedly happened in Surselvan. Mendrisiot and Luganese (West Lombard) are not completely there, but close enough. They show some variation between simple and double forms: $5^{\text {th }}$ person is always marked by the originally $3^{\text {rd }}$ person form $(s a)$, but the original form $v a$ may be added to it: vialtrisUBJ $s a_{\mathrm{REFL}}$ làvuf/vialtri $i_{\mathrm{SUBJ}} s a_{\mathrm{REFL}} v a_{\mathrm{REFL}}$ làvuf 'you wash yourselves'. The $1^{\text {st }}$ 
Quite interestingly, intermediate situations between fully functionally and fully strategically streamlined reflexive systems are found in several Romance varieties. This is exactly the case in Rhaeto-Romance and in the Northern Italian dialects, where a considerable amount of variation is found (and, to a lesser extent, in some other substandard Romance varieties). ${ }^{8}$ According to the typological research reviewed in the previous section (Faltz 1985, Benincà \& Poletto 2005, Puddu 2010), we should expect the following possibilities shown in (7), while any others are unpredicted.

$$
\begin{aligned}
& \text { a. } 3^{\text {rd }} / 6^{\text {th }}=5^{\text {th }} \\
& \text { a' } 3^{\text {rd }} / 6^{\text {th }}=4^{\text {th }} \\
& \text { b. } 3^{\text {rd }} / 6^{\text {th }}=5^{\text {th }}=4^{\text {th }} \\
& \text { c. } 3^{\text {rd }} / 6^{\text {th }}=5^{\text {th }}=4^{\text {th }}=2^{\text {nd }} \\
& \text { c. } \cdot 3^{\text {rd }} / 6^{\text {th }}=5^{\text {th }}=4^{\text {th }}=1^{\text {st } 9} \\
& \text { d. } 3^{\text {rd }} / 6^{\text {th }}=5^{\text {th }}=4^{\text {th }}=2^{\text {nd }}=1^{\text {st }}
\end{aligned}
$$

Both possibilities in (7a, 7a') are attested in Romance, but (7a') seems to be the most frequent by far. Syncretism between the $3^{\text {rd }}$ person and the $4^{\text {th }}$ is found in Gherdëina (Ladin), ${ }^{10}$ Alessandrine, Turinese and the dialect of Ceva (Piedmontese), Bolognese, the dialects of Bobbio and Roccabianca (Emilian), Genoese (Ligurian), Cremonese (Lombard) and in Supradialectal Venetan (Meneghin 2008). Marco Tamburelli (p. c.) confirms that most Lombard varieties either allow this $3^{\text {rd }} / 4^{\text {th }}$ person syncretism or show the syncretism in all persons in the plural. Puddu (2010) also attests the $3^{\text {rd }} / 4^{\text {th }}$ syncretism in Piedmontese and Venetan. Meyer-Lübke (1906: $\$ 380)$ notices that the use of $s e$ in the $4^{\text {th }}$ person is common all across Northern Italy and in Southern Provençal. Ronjat (1937) corroborates this for Provençal and Blanchet (1992) considers the syncretism to be the norm in that variety. Quint (1998) also attests the syncretism in the Vivaro-Alpine Occitan dialect (to the North of the Provençal domain), but other works on the Occitan language mention that this kind of syncretism is rare (Carrera 2011; Quint 1999). This apparent discrepancy seems to suggest that the reflexive syncretism is not the norm in Occitan, although definitely common in the East of the domain. One example of this syncretism is displayed in (8), from Genoese.

person is obligatorily marked by $m a$, but admits doubling with $s a$ : $m i_{\text {SUBJ }} m a_{\text {REFL }}$ lavi/misUBJ $m a_{\text {REFL }} s a_{\text {REFL }}$ lavi 'I wash myself' (Meneghin 2008). strategically streamlined paradigm. Some varieties, such as Surmiran, Rumantsch Grischon (Romansh/Rhaeto-Romance), the dialect of Riva (Lombard) and Orbasque (Piedmontese), show a fully preserved functionally streamlined reflexive system (Meneghin 2008).

$9 \quad$ Since Faltz (1985) only predicted the order $3^{\text {rd }}>2^{\text {nd }}>1^{\text {st }},\left(6 a^{\prime}\right)$ and $\left(6 c^{\prime}\right)$ are unexpected in his account. However, as said before, Puddu (2010) and Benincà \& Poletto (2005) already found counterexamples to Faltz's person hierarchy. On the other hand, (6a) and also (6c') are unexpected according to Benincà \& Poletto (2005). Puddu does not make any prediction on whether the same person hierarchy should be followed in the plural and in the singular, but from Northern Italian varieties it is clear that this is not the case, since the most common evolution in the plural is $3^{\text {rd }} / 6^{\text {th }}>4^{\text {th }}>5^{\text {th }}$ and afterwards it reaches the $2^{\text {nd }}$ singular.

The syncretism is only found with reflexive meaning, while reciprocal verbs preserve nes in Gherdëina (Meneghin p. c.). 


\begin{tabular}{|c|c|}
\hline$\hat{a}-s e$ 'to wash & $08)^{1}$ \\
\hline mi $_{\text {SUBJ }}$ me $_{\text {REFL }}$ lavo & 'I wash myself' \\
\hline ti $_{\text {SUBJ }}$ ti $i_{\text {SUBJ.CL }}$ te $e_{\text {REFL lavi }}$ & 'You wash yourself' \\
\hline lê $\hat{\mathrm{SUBJ}}_{\mathrm{SUBJ} . \mathrm{CL}} s e_{\mathrm{REFL}}$ lava & 'He, she washes himself, herself' \\
\hline trisUBJ $s e_{\text {REFL lavemmo }}$ & 'We wash ourselves' \\
\hline atri $_{\text {SUBJ }} v_{\text {REFL lavæ }}$ & 'You wash yourselves' \\
\hline SUBJ $s e_{\text {REFL làvan }}$ & 'They wash themselves' \\
\hline
\end{tabular}

(Genoese)

Contrary to what Benincà \& Poletto (2005) claim, the syncretism between only the $3^{\text {rd }}$ and the $5^{\text {th }}$ persons, although more rare, is also possible in Romance. They actually had a counterexample to their own claim in Trieste, which they attribute to Slavic contact. ${ }^{12}$ But that is not the only exception attested in Romance: both Vallader and Puter (Romansh/Rhaeto-Romance) present the solution in (7a):

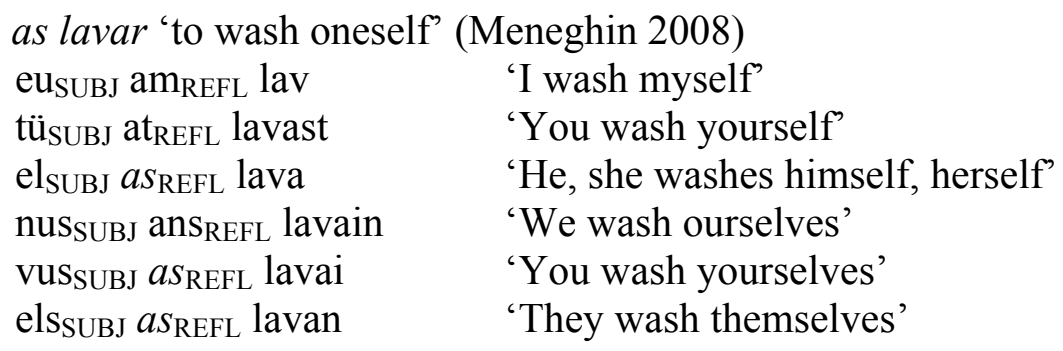

(Vallader, Puter)

Syncretism in all the plural persons, $(7 \mathrm{~b})$, is also attested in several Romance varieties. Meneghin (2008) finds it in Val Badia, Ladin Dolomitan, Standard Friulian and in Bregagliot (Lombard). ${ }^{13}$ As said above, Marco Tamburelli (p. c.) also confirms the existence of this paradigm in Lombard. Meyer-Lübke (1906: §380) also documents it in Friulian. According to Puddu (2010), Campidanese Sardinian can be added to the list. Herzog (1914) states that, in French dialects, se is sometimes used in all the persons of the plural. ${ }^{14}$ This solution is also found in some substandard varieties of Catalan (see

11 For the ease of interpretation, I will gloss the paradigms using subscript abbreviations. SUBJ stands for 'subject', REFL for 'reflexive' (which may appear twice, as some varieties have double forms) and SUBJ.CL for 'subject clitic'.

12 Unfortunantely, they do not elaborate this hypothesis further. Since Standard Slovene has a fully strategically streamlined reflexive paradigm with a unique reflexive pronoun sêbe for all persons (Herrity 2000), it is hard to see how the contact hypothesis could explain the allegedly anomalous behaviour of Trieste's dialect (unless it were contact with a Substandard Slovene variety that had $s e$ only in the $3^{\text {rd }}$ and the $5^{\text {th }}$ persons, but nothing of the kind is alleged in Benincà \& Poletto's paper).

Bregagliot admits both the etymologically $5^{\text {th }}$ person form $u v$ and the syncretic $u s$ $\left(u_{\text {SUBJ.CL }} a s_{\text {REFL }}\right)$ (Giacometti 2003: 65-68), suggesting that the extension of the spread was $3^{\text {rd }} / 6^{\text {th }}>4^{\text {th }}>5^{\text {th }}$. Dolomitic Ladin admits variation between $s e$ and both the $4^{\text {th }}$ and the $5^{\text {th }}$ person forms nes, ves.

However, Herzog only provides examples of syncretism in the $5^{\text {th }}$ person: vous se portez 'you.PL 3.REFL go' (Champlemy, Bourgogne; Nivernais dialect) and vous s'imaginez 'you.PL 3.REFL imagine' (Saint-Pol, Faubourgs; Picard dialect). Johannes Kabatek kindly provides me with the following example (also a $5^{\text {th }}$ person), vous voulez aller se coucher-là [you.PL want.2PL go 3.REFL lay.down there "you want to go lay down there'], from the French film Bienvenue chez les ch'tis, which features the "strange" speech in the North of the country (specifically the region Nord/Pas de Calais, right to the North of the Picardy region). Of course, this example cannot be seen as proof of the construction in this area, but it definitely shows that the phenomenon exists in French 
also section 4.2). Fabra (1913-14) attests it in the speech of (mostly the lower classes of) Barcelona and Badia i Margarit (1962) considers this use a pervasive feature of Substandard Catalan. Alcover \& Moll (1968) show many examples of this syncretism in Catalan, noticing that it seems more frequent in Valencian, whereas it is unattested in Balearic. Several grammars on Valencian confirm this suspicion (mostly by condemning the use): Guinot i Galan (1987), Salvador (1974) and Sanchis Guarner (1950) also attest (and disapprove of) it. In his sociolinguistic study of Sagunto (Castelló), Gómez Molina (1986) indicates that this use of se is especially common in informal speech. All these Catalan varieties show variation, accepting both the unequivocally reflexive form se and the original forms (nos, vos or its dialectal allomorphs) for the $4^{\text {th }}$ and $5^{\text {th }}$ reflexive pronoun. An example of this syncretism is presented in (10), from the Dolomitic Ladin variety spoken in Val Badia:

$$
\begin{aligned}
& \text { se lavè 'to wash oneself' (Meneghin 2008) }
\end{aligned}
$$

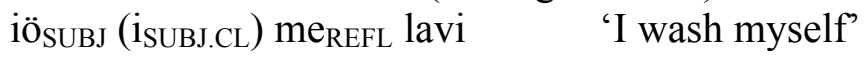

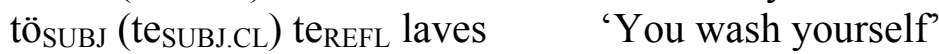

$$
\begin{aligned}
& \text { ël } 1_{\text {SUBJ }}\left(\mathrm{al}_{\text {SUBJ.CL }}\right) s e_{\text {REFL lava }} \text { 'He, she washes himself, herself' } \\
& \text { nos } \left.\text { SUBJ }_{\text {(SUBJ.CL }}\right) s e_{\text {REFL lavun }} \text { 'We wash ourselves' }
\end{aligned}
$$

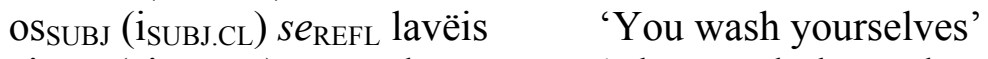

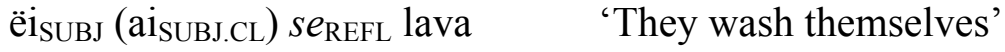

(Val Badia)

Of the possibilities in (7c, 7c'), only (7c) (all the plural persons and also the $2^{\text {nd }}$ are syncretic with the $3^{\text {rd }}$ ) is attested in Romance, as far as I know. This pattern is found in some Northern Italian varieties, namely, the dialect of Medeglia (West Lombard), in Poschiavino (Lombard) (Meneghin 2008) ${ }^{15}$ and Milanese (Puddu 2010). I give an example of this distribution in (11), from the variety spoken in Medglia.

$$
\begin{aligned}
& \text { laváss 'to wash oneself' (Meneghin 2008) }
\end{aligned}
$$

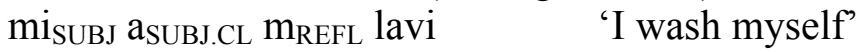

$$
\begin{aligned}
& \text { tisUBJ } t u_{\text {SUBJ.CL }} s_{\text {REFL lavi }} \text { 'You wash yourself' } \\
& \text { lüüsUBJ } u_{\text {SUBJ.CL }} s_{\text {REFL lava }} \text { 'He, she washes himself, herself' }
\end{aligned}
$$



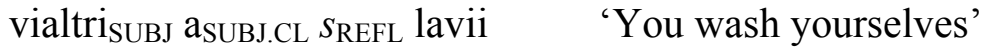

$$
\begin{aligned}
& \text { luur }_{\text {SUBJ }} \text { is } s_{\text {SUBJ.CL-REFL lave }}
\end{aligned}
$$

(Medeglia)

To my knowledge, syncretism in all persons but the $2^{\text {nd }}$ (the solution in $7 c^{\prime}$ ) is not attested in any Romance language. But the Northern Italian dialects also exemplify a solution not completely predicted by Puddu's typological generalisation (plural > singular): the syncretism between the $3^{\text {rd }}$, the $4^{\text {th }}$ and the $2^{\text {nd }}$ persons, but not the $5^{\text {th }}$. According to Meneghin (2008), this is exactly the situation in Milanese and Airolo (although in Airolo the $2^{\text {nd }}$ person has a double form: $t i$ ti $t$ s làvat). However, Puddu (2010) claims that in Milanese the $3^{\text {rd }}$ person reflexive has also extended to the $5^{\text {th }}$ person,

In Poschiavino (Lombard), there is variation between simple forms and double forms, with $s e$ and the original pronoun $(t a, m a, v a)$ in all these persons: $t i_{\text {SUBJ }} t a_{\text {SUBJ.CL }} s a_{\text {REFL }}$ làvas/ti $i_{\mathrm{SUBJ}} t a_{\mathrm{SUBJ} . C L} s a_{\mathrm{REFL}} t a_{\mathrm{REFL}}$ làvas 'you wash yourself'; nualtri $i_{\mathrm{SUBJ}} m a_{\mathrm{REFL}}$ làvum/nualtri $i_{\mathrm{SUBJ}} m a_{\mathrm{REFL}} s a_{\mathrm{REFL}}$ làvum 'we wash ourselves', vualtri $i_{\mathrm{SUBJ}} v a_{\mathrm{REFL}}$ làvuv/vualtri SUBJ $v a_{\mathrm{REFL}} s a_{\mathrm{REFL}}$ làvuv 'You wash yourselves'. Interestingly, in such a paradigm the only person other than the $3^{\text {rd }}$ that always shows $s a$ is the $2^{\text {nd }}$ (singular). 
so more data on this variety would be very welcome. On this regard, it is interesting to recall that Meneghin (2008) attests optional double forms in the $1^{\text {st }}\left(\mathrm{ma} / \mathrm{ma} \mathrm{sa}\right.$ ) and the $5^{\text {th }}$ ( $s a / s a v a$ ), but not in the $2^{\text {nd }}$ (where only the corresponding se form is used) in Mendrisiot and Luganese, which could also suggest that the syncretism developed first in the $2^{\text {nd }}$ than in the $5^{\text {th }}$ (cf. note 6) -although it may also be the case that the doubling and the syncretism evolve independently. Airolo's paradigm is given in (12).

$$
\begin{aligned}
& \text { lavàss 'to wash oneself' (Meneghin 2008) } \\
& \text { mi }_{\text {SUBJ }} \text { im }_{\text {SUBJ.CL-REFL lavi }} \\
& \text { ti }_{\text {SUBJ }} \text { ti } i_{\text {SUBJ.CL }} t_{\text {REFL }} s_{\text {REFL }} \text { làvat } \\
& \text { lüi } i_{S U B J} \text { us } s_{\text {SUBJ.CL-REFL lava }}
\end{aligned}
$$

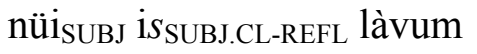

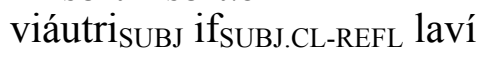

$$
\begin{aligned}
& \text { lósUBJ is } s_{\text {SUBJ.CL-REFL làvan }}
\end{aligned}
$$

(Airolo)

\author{
'I wash myself' \\ 'You wash yourself' \\ 'He, she washes himself' \\ 'We wash ourselves' \\ 'You wash yourselves' \\ 'They wash themselves'
}

From a typological point of view, then, it seems that the generalization proposed by Puddu (2010) may need to be qualified. So far, the patterns attested in the Romance varieties I just reviewed allow for the reconstruction of the evolutions in (13) - but note that (13c) seems to be quite exceptional in our sample.

$$
\begin{aligned}
& \text { a. } 3>5 \\
& \text { a'. } 3>4 \\
& \text { b. } 3>4,5>2 \\
& \text { c. } 3>4>2
\end{aligned}
$$

The syncretism has also been attested in Ibero-Romance varieties across the Atlantic Ocean. According to Vidal de Battini (1964), se is used as the $4^{\text {th }}$ person reflexive pronoun in the speech of uneducated people from several areas in Argentina (in Río de la Plata, in the Northern region and in the Western Cuyo region). It is, of course, also used in the $5^{\text {th }}$, since the $5^{\text {th }}$ person subject pronoun vosotros/as has been replaced by ustedes. Ustedes was originally (and still is in most dialects of Peninsular Spanish) a polite address plural pronoun, which triggers $6^{\text {th }}$ person agreement (since it derives from the plural noun phrase vuestras mercedes 'your graces'). In these varieties, then, se is generalised as the only reflexive form in the plural. Kany (1945) explains that Lafone Quevedo (1898) attributes this development to Quechuan influence in Catamarca, while he proposes that the cases found in Buenos Aires may be due to Italian influence. He thinks nevertheless that the syncretism was most likely inherited from Spain, since se is frequently used instead of os (the $5^{\text {th }}$ person object pronoun) in Andalusia and Murcia. ${ }^{16}$ However, the fact that the syncretism is found in different persons in Spain and in Argentina poses some problems for such an explanation.

16 Martín Zorraquino (1979) also groups, for explanatory purposes, the Argentinian uses with the examples of $5^{\text {th }}$ person se found in Western Andalusia and Murcia. Although the examples in Western Andalusia probably share a common origin with the extension in Eastern Spanish (cf. section 4.1), they are not examples of a change in the reflexive paradigm but of the loss of the $2^{\text {nd }}$ person nominative vosotros and its substitution by ustedes in Western Andalusia. In this area, the $6^{\text {th }}$ person agreement that ustedes triggers in most varieties of Spanish has been replaced by the $5^{\text {th }}$ agreement in both pronouns and verbal forms to different extents, so that examples such as Ustedes se quieren sentar (You.PL 3.REF want.3PL sit-down); Ustedes se queréis sentar (You.PL 3.REF want.2PL sitdown), Ustedes os queréis sentar (You.PL 2.ACC want.2PL sit-down), A ustedes los vieron 
I have only managed to find one reference to the use of se instead of nos $\left(4^{\text {th }}\right.$ person) in Peninsular Spanish: Blas Arroyo et al. (1992) describe it in Castelló (Valencian Country) and consider it a Catalan (Valencian) interference. ${ }^{17}$

In Brazilian Portuguese, the use of the $3^{\text {rd }}$ person reflexive pronoun $s e$ in other persons can be seen as a Pan-Brazilian phenomenon, according to de Oliveira (2005). The situation there, as is usually the case in Brazilian Portuguese, is quite diverse. In many (most) varieties, every subject pronoun but the $1^{\text {st }}$ person triggers $3^{\text {rd }}$ person agreement (singular or plural), as a result of the reorganization of the pronominal paradigm. On the one hand, the $2^{\text {nd }}$ person forms have been replaced by the previously formal pronouns você $(s)$ and, on the other, the $4^{\text {th }}$ person pronoun has been replaced by the form a gente. All these forms historically derive from etymologically $3^{\text {rd }}$ person noun phrases, which trigger $3^{\text {rd }}$ person (singular or plural) agreement. Thus, in these varieties, all persons except for the $1^{\text {st }}$ agree syntactically with a $3^{\text {rd }}$ person reflexive pronoun $(s e)$. It does not seem unlikely, then, that in some varieties se could appear also in the $1^{\text {st }}$ person, a development that would imply an absolute regularisation of the reflexive paradigm. This is the case in Afro-Brazilian Portuguese, for example, where $s e$ is also attested as the $1^{\text {st }}$ person reflexive pronoun, alternating with me (Alves de Souza 2011).

However, the neutralization of the reflexive form is also found in varieties that preserve some of the original pronouns. For example, the São Paulo dialect preserves the $4^{\text {th }}$ person pronoun nós, but se is attested in all persons, including the $1^{\text {st }}(\mathrm{eu})$ and the $4^{\text {th }}$ (da Silveira 2008; de Oliveira, 2005). In Northern varieties, where both nós and the $2^{\text {nd }}$ person pronoun $t u$ are preserved, reflexive $s e$ is attested with both of them, meaning that the only person that escapes the syncretism is the $1^{\text {st }}$ (de Oliveira, 2005). In Mozambican Portuguese, according to de Oliveira (2005), se is also attested in the $4^{\text {th }}$ person (with the $4^{\text {th }}$ person subject pronoun nós).

It is especially interesting that, although the syncretism is found in so many Romance varieties, quite diverse origins have been proposed for the different varieties. Meyer-Lübke (1906) believes that phonetic proximity between the reflexive and the non-reflexive pronouns may have originated the syncretism in Rhaeto-Romance and Southwest France varieties. Further evidence supporting this would be the fact that, according to Ronjat (1937), in several Provençal dialects se can be used as a nonreflexive pronoun, as in apère-se 'call us'. Although he believes that the use of se instead of reflexive nos is the original context, from which se would have extended to non-reflexive environments, he also thinks that phonetic weakening of nos may have played a role in this development. Meneghin (2008) also finds plausible that phonetic reduction of the $4^{\text {th }}$ person clitic (after having crossed with the subject clitic: a nos $>a$ nes $>$ ans $>$ as) may have caused the syncretism with the $3^{\text {rd }}$ person (after a similar

(To you.PL 3PL.ACC saw.3PL 'They saw you') and $A$ ustedes os vieron (To you.PL 2PL.ACC saw.3PL 'They saw you') are possible (cf. Lara Bermejo 2012).

Unfortunately, it seems that the possibility of resorting to language contact has some responsibility in the lack of studies of these developments in Spanish. While Lafone Quevedo does support his contact hypothesis by comparing the Spanish reflexive with the Quechuan reflexive suffix $-k u$ (he transcribes it $-c u$ ), which is identical in every person, Kany adds no more to his hypothesis. Whether this Italian influence is due to contact with Northern varieties that also show the extension, to the phonetic similarity of the $4^{\text {th }}$ person object pronoun in Italian, $c i$ or to some other possibility, it is to the reader to decide. On the other hand, Blas Arroyo et al. (1992) attribute this feature to Catalan influence because the phenomenon is described in Valencian grammars, although this only raises more questions: how did it happen in Valencian?; how can we know the direction of the interference (if it is actually one)? 
development: /al sə/ > /als/ > /as/) in the Rhaeto-Cisalpine domain ${ }^{18}$. As he notes, this hypothesis would be reinforced by the fact that Emilian dialects show variation between als and as in the $4^{\text {th }}$ person.

In some varieties, however, phonetic reasons must be necessarily ruled out. Meyer-Lübke (1906) finds them inapplicable in Veglia and proposes that the situation there may be due to Slavic influence, as Benincà \& Poletto (2005) do for the variety spoken in Trieste. A different kind of contact, that with the Standard Italian form $c i$ diamo (we.REFL give.1PL), could explain the confusion in some Italian dialects (like Venetian or Genoese), but not in others (Lombard, Emilian, Tuscan) or in Provençal, also according to Meyer-Lübke (1906). He similarly discards a possible Genoese influence on Provençal, for example, because in the latter the phenomenon is too widespread. As we saw, Blas Arroyo et al. (1992) also attribute the syncretism in the Spanish of Castelló (Valencian Country) to contact with Catalan.

A different kind of explanation is proposed by Meneghin (2008), concerning the extension to the $2^{\text {nd }}$ person. According to him, the use of $s e$ in the $2^{\text {nd }}$ person in some Northern Italian varieties, like Ticinese, is best explained by the fact that $2^{\text {nd }}$ person verbs are compulsorily preceded by at least the unstressed subject clitic, which is identical to the $2^{\text {nd }}$ person object pronoun. The use of the unequivocally reflexive form se would hence avoid the repetition of the $2^{\text {nd }}$ person pronoun two times and make clearer the reflexive interpretation. He finds further support to this hypothesis in varieties like Ticinese, where (ti) ta nètat/nètas 'you.SG clean' and (ti) ta sa nètat/nètas 'you.SG clean yourself', but *(ti) ta ta nètat/nètas 'you.SG clean yourself'.

Although internal pressure from a pronominal paradigm where most pronouns trigger $3^{\text {rd }}$ person agreement may explain the syncretism in some varieties of Brazilian Portuguese, we saw that not all of them show such a homogenous paradigm. I have not found any explanations for the extension of se in Portuguese in the literature, except for Castilho (1997), who states that reflexives tend to generalise in all persons, especially in non-standard languages, which is of course more of a description of a common crosslinguistic situation than an actual explanation.

I would like to end this overview of the reflexive paradigms in Romance by mentioning a somehow similar phenomenon that has been attested in European Portuguese. Martins (2003) finds that in some varieties of Madeira and Porto Santo, se may appear in sentences with non $3^{\text {rd }}$ person verbs. These sentences do not contain, however, reflexive verbs, but this seems to be an indefinite se indicating that the sentence has a generic or indefinite subject (which may or may not be overt). As can be seen in the examples in (14), this indefinite se also appears with $3^{\text {rd }}$ person (nonreflexive) verbs $(14 b, c)$.

18 Such a hypothesis or a slightly broader one in which the fusion of the subject clitic and the reflexive pronoun would have created a syncretic reflexive reduced form $-s$ for two or more persons in the plural can be alleged for several Northern Italian varieties: Airolo (West Lombard), dialect of Ceva, Orbasque, Alessandrine (Piedmontese), dialect of Bobbio, dialect of Roccabianca and Bolognese (Emilian). 
CORDIAL-SIN ${ }^{19}$

a. Nunca se vimos este peixe (Câmara de Lobos, Madeira, CLC 18)

Never 3.REFL saw.1PL this fish

'We never saw such a fish'

b. A gente via-se elas [as baleias] longe

(Caniçal, Madeira, CLC 32)

The people saw.3SG-3REFL them.3PL [the wales] far

'The people saw them [the whales] far away'

c. Oh, era um pano que a gente se punha [na caixa do moinho]

(Tanque, Porto Santo, PST 23)

Oh was.2SG a cloth that the people 3.REFL put [in.the box of.the mill]

'Oh, that was a cloth that people used to put (in the mill box)'

I have found similar examples in Eastern Spanish, where se appears with either $4^{\text {th }}(15 \mathrm{a}, \mathrm{b}), 2^{\text {nd }}(15 \mathrm{c})$ or even $6^{\text {th }}$ person verbal forms with a singular object $(15 \mathrm{~d})$ in sentences with indefinite subjects (cf. also de Benito 2010 for some evidence of this construction in the ALPI).

COSER

$(\text { Spanish })^{20}$

a. [Y, ¿cuál es la Virgen?] Santa Quiteria. Y se le (Higueruela, ALB 211) [And, who is the Virgin?] Saint Quiteria. And 3.REFL 3SG.DAT

'[And, who is the Virgin?] Saint Quiteria. And'

tenemos mucha devoción

have.1PL much devotion.

'we are very devoted to her.'

b. Yo creo, no sé si será la palabra,

I think not know.1SG if be.3SG.FUT the word

'I think, I don't know if that's the proper word'

pero se decimos "acurrucarte"

but 3.REF say.1PL curl.up-2SG.REFL

"but we say "curling up"

c. [Talking about how they used to dye wool]

Pues, se comprabas el tinte, lo ponías en una cacerola $[\ldots]$
Well, 3.REFL bought.2SG the dye, it.ACC put.IPFV.2SG in a saucepan

(Urriés, ZA 4720)

'Well, you had to buy the dye, put it in a saucepan [...]'

19 CORDIAL-SYN (Syntax-Oriented Corpus of Portuguese Dialects) is a corpus of semidirected interviews to rural speakers from 42 different villages in Portugal, collected by researchers from the Centro de Linguística da Universidade de Lisboa and is available at http://www.clul.ul.pt/en/resources/411-cordial-corpus. use the following: AL (Alacant), ALB (Albacete), BA (Badajoz), BAR (Barcelona), CA (Castellón), GE (Gerona), MU (Murcia), TA (Tarragona), VA (Valencia) and ZA (Zaragoza). When the examples come from the COSER, the province is followed by the numeric code that identifies each village in the corpus. 
d. [Talking about the celebration that took place before the young men left to the military service]

Pues cada, pues se, se invitaban uno en cada casa,

Well every, well 3.REFL, 3.REFL invited.3PL one in every house

'Well, every..., well, they invited one to every house,'

uno, uno en cada $\mid$ con los que había

one, one in every with the.M.PL that were.3SG

'one, one to every..., with those that were there'

These Spanish and Portuguese examples could be the result of fusing two impersonalising devices. In Spanish, non-specific subjects may be indicated by two main means. On the one hand, the reflexive passive and the reflexive impersonal constructions, marked by the reflexive pronoun se. On the other, $2^{\text {nd }}, 4^{\text {th }}$ and $6^{\text {th }}$ person verbal morphology can also form generic or indefinite agent constructions. Although the examples in Spanish are quite sporadic, the fact that they were found in Eastern Spanish may suggest some relationship with the extension of se to other persons that should be further explored when more data are available.

I will now turn to describe the reflexive syncretism found in Peninsular Spanish and Valencian Catalan and try to see how it fits in the hierarchies and developments found in the Romance varieties reviewed in this section.

\section{The reflexive paradigm in the Valencian Country and Murcia}

To my knowledge, there are no studies focusing specifically on the extension of reflexive se to other persons in either Spanish or Catalan, although, as seen above, there are some mentions in the literature. In this section I will be looking at this syncretism in the Valencian Country and Murcia in both Spanish and Catalan.

Most of the data in the present study come from the COSER. The corpus consists of semi-directed interviews (also known as sociolinguistic interviews) targeting elderly, rural, non-mobile and low educated speakers from all around the Spanishspeaking area in Spain. The interviews' duration is variable, but the mean is around 75 minutes per village.

For this paper I use data from 19 different villages in València, Castelló, Alacant and Murcia. Since these provinces were only enquired in September 2013 and most of the interviews have not been transcribed yet, I first checked the interviewers' field notes in order to see in which localities the syncretism had been attested. I afterwards heard those 19 interviews and transcribed all the examples of $4^{\text {th }}$ and $5^{\text {th }}$ person reflexive verbal forms, since in the field notes there was no notice of the syncretism appearing in the singular. In the end, I got a corpus of 385 examples of $4^{\text {th }}$ and $5^{\text {th }}$ person reflexive verbal forms.

I also use data from the Linguistic Atlas of the Iberian Peninsula (ALPI from now on, for its acronym in Spanish). ${ }^{21}$ Most of the ALPI interviews took place in the 1930s, but the Spanish Civil War interrupted the project, which had to be completed between 1947-1956 (for more information on the ALPI's history, cf. the introduction to the only published volume, ALPI (1962) and also Navarro Tomás (1975) and Heap

21 Only the first volume of the ALPI was published, but the materials are both available online (http://westernlinguistics.ca/alpi/) and at the Universidad Autónoma de Madrid, where I could complete some information that was missing from the website materials. 
(2003)). Hence, there is a gap of around 80 years between the earliest ALPI campaigns (where all the Spanish and most of the Catalan data was obtained) and the COSER interviews I will be looking at, which allows for some historical perspective.

Unfortunately, the interviews collected in the Dialectal Spoken Corpus (from now on, COD, for its acronym in Catalan) do not attest any example of the syncretism in the variety of Catalan spoken in the Valencian Country. This contrast with the COSER data may be due to two different reasons. On the one hand, the interviewees were younger and more educated and the settings larger than those in the COSER, which could hinder the occurrence of a substandard phenomenon like this one. On the other hand, the available transcriptions correspond to much shorter recordings (of around 10 minutes). Actually, out of 8 interviews (Elx, La Vila Joiosa, Alacant, Sueca (Alacant), L'Alcora, Morella (Castelló), Llíria and València (València)), only one case of $5^{\text {th }}$ person reflexive verbal forms and 13 cases of $4^{\text {th }}$ person reflexive verbal forms were found (none of them with the syncretism). I will thus be using the data from the COD questionnaires (not available online) as presented in Perea (2012) and from Alcover's materials as presented in Perea (2012) and Alcover \& Moll (1968). ${ }^{22}$

In the remainder of this section I will describe these data and propose a hypothesis regarding the diachronic extension of se to other persons in Spanish. I will also connect this development to the situation in Catalan, although I will not propose a diachronic hypothesis for this language.

\subsection{The syncretism in Spanish}

Some, although very scarce, references to the syncretism can be found in dialectal works. Nebot Calpe (1984) notices that se instead of $5^{\text {th }}$ person os occurs (but not regularly) in the Aragonese dialect of Spanish spoken in the provinces of València and Castelló and that it is most common with reflexive verbs (implying that it may also appear in non-reflexive contexts) and so are all her examples. She attributes it to Valencian contact, without further explanation. Some of her examples are given in (16).

Nebot Calpe (1984)

a. Se laváis to los días a desgusto

(Spanish)

3.REFL wash.2PL all the days to unpleasure

'Every day you guys take a shower while complaining'

b. ¿se vais a casa la mare?

3.REFL go.2Pl to house the mother

‘A Are you guys going to your mum's?'

c. se lo topetastis a mi primo en el embolau d' Argelita 3.REFL him.ACC found.2PL to my cousin in the bulls.on.fire of Argelita

'You guys ran into my cousin in the "Bulls-on-fire" feast of Argelita'

Guillén García (1974) and García Cotorruelo (1959) confirm the use of se as a $5^{\text {th }}$ person pronoun in Orihuela (Alacant) and Cartagena (Murcia), two areas generally conceived as belonging to the Murcian Spanish dialect. They do not mention contact with Catalan as a possible explanation, unsurprisingly, since these areas have been monolingual in Spanish for seven centuries.

22 These materials include Alcover's fieldwork notebooks (1900-1923) and the data in "La flexió verbal en els dialectes catalans" and "Estudis de Sintaxis dialectal catalana" (edited in two parts in 1916, Bolletí del diccionari de la llengua catalana (BDLC), IX (11-37 and 49-63), see Perea (2012)). 
Blas Arroyo et al. (1992) mention the use of se instead of $4^{\text {th }}$ person nos as a typical feature of the speech of Castelló (Valencian Country) and, as said above, they consider it a calque from Valencian (Catalan). ${ }^{23}$ In the COSER interviews the syncretism was found both in Spanish monolinguals and in Spanish-Catalan bilinguals. This does not necessarily rule out the contact hypothesis as the origin of the innovation, but would imply that the interference settled well enough so as to spread to the monolingual contiguous area.

The geographical distribution of the phenomenon in Spanish according to the COSER data is presented in map 1.

\section{Map 1. The reflexive syncretism in Eastern Spanish ${ }^{24}$}

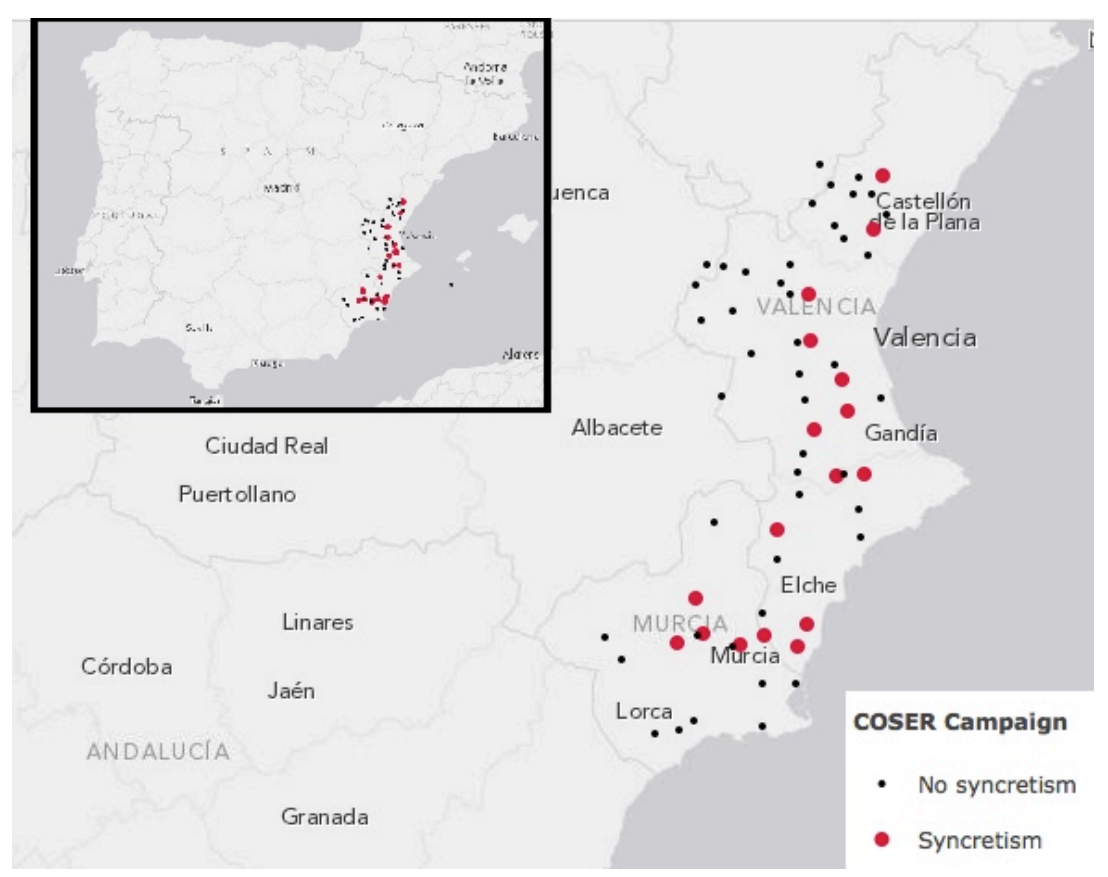

The same interpretation is attributed in a commentary to the only example found in the PRESEEA (Project for the sociolinguistic study of Spain's and America's Spanish) corpus from Valencia: la gente joven pensamos de otra manera se pensamos que somos los reyes del volante (the young people, think.1PL different, 3.REFL think.1PL that are. $1 \mathrm{PL}$ the kings of the driving.wheel). Unfortunately, there are no examples of the syncretism in the Corpus Sociolingüistico de Castellón de la Plana y su área metropolitana-Sociolinguistic corpus of Castellón de la Plana and its metropolitan area-(Blas Arroyo et al. 2009).

The villages that presented the reflexive syncretism (in red) are the following: Lucena del Cid (COSER 1308) and Ahín (COSER 1301) in Castelló; Pedralba (COSER 4318), Turís (COSER 4324), Benimodo (COSER 4306), Sant Joanet (COSER 4321) and Enguera (COSER 4310) in València; Benimarfull (COSER 303), Salinas (COSER 310), Benijófar (COSER 302), El Mojón (COSER 306), San Miguel de Salinas (COSER 311) and Alfafara (COSER 310) in Alacant; Abarán (COSER 3102), Campos del Río (COSER 3104), Pliego (COSER 3112) and Palacios Blancos (COSER 3111) in Murcia. La Romaneta (COSER 308, Alacant) and Villar del Arzobispo (COSER 4325, València), although showing examples of $5^{\text {th }}$ person $s e$, are not represented as having the syncretism in the map, for they were all in the imperative. The especial status of se with the imperative is explained below. 
The COSER data show that, although the extension of se is quite common, it is definitely not the norm and the standard forms are usually preferred (in a 69,09\% of the total cases). In only two villages-Lucena del Cid (COSER 1308, Castelló) and Benimarfull (COSER 303, Alacant) - the speaker presented a consistent use of se in both the $4^{\text {th }}$ and the $5^{\text {th }}$ persons. Some others only showed a few sporadic examples and still some others presented quite a lot of variation. ${ }^{25}$ It also needs to be said that when there is more than one speaker in the same place, the situation can dramatically change from one speaker to another, going even from an apparent absence of the syncretism to an apparent exclusive use of $s e .^{26}$ Table 1 presents the global data obtained from the COSER.

Table $1.4^{\text {th }}$ and $5^{\text {th }}$ reflexive pronouns in the COSER interviews

\begin{tabular}{l|rrr|}
\multicolumn{1}{c}{} & $4^{\text {th }}$ person & $\mathbf{5}^{\text {th }}$ person & Total \\
\hline se & 69 & 50 & 119 \\
se $\%$ & $22.55 \%$ & $63.29 \%$ & $30.91 \%$ \\
nos/los $/$ os & 237 & 29 & 266 \\
nos/los/os $\%$ & $77.45 \%$ & $36.71 \%$ & $69.09 \%$ \\
Total & 306 & 79 & 385 \\
p $=7.409 \mathrm{e}^{-12}$ & $(<0,05)^{27}$ & &
\end{tabular}

The data in table 1 indicate that the use of $s e$ is much more common in the $5^{\text {th }}$ person than in the $4^{\text {th }}$ and that this difference is highly significant, as the very small $p$ value $\left(7.409 \mathrm{e}^{-12}\right)$ indicates. ${ }^{28}$ This would suggest an evolution $3^{\text {rd }} / 6^{\text {th }}>5^{\text {th }}>4^{\text {th }}$, the least common in the Rhaeto-Romanic and Northern Italian varieties - and rejected as a possible Romance evolution in Benincà \& Poletto (2005). The geographical distribution of the COSER data supports such a hypothesis, since $4^{\text {th }}$ person se occurs in a more restricted area (it is almost absent in Murcia). This could suggest that the focus of the phenomenon is in the Valencian Country.

25 There were six interviews that provided only one example each: Benimodo (COSER 4306), Sant Joanet (COSER 4321), San Miguel de Salinas (COSER 311), and one of two interviews in El Mojón (COSER 306), Alfafara (COSER 310) and Villar del Arzobispo (COSER 4325). Of the two speakers in Pedralba (COSER 4318), one of them uttered 16 examples of $4^{\text {th }}$ and $5^{\text {th }}$ person reflexive verbal forms, none of which presented $s e$; whereas the other speaker provided only 4 examples, all of them with se. All the $\mathrm{p}$ values were calculated with Pearson's Chi-squared test with Yates' continuity correction, using the software R.

The big difference between the total occurrences of the $4^{\text {th }}$ and the $5^{\text {th }}$ persons is explained by the fact that our data come from interviews and not free conversation samples, hence the speakers refer more often to themselves and their peers than to the interviewers. Although more data (in any of the slots) would be very welcome and insightful, the robustness of the $\mathrm{p}$ value (which controls for these differences) suggests that our results are on the right track. 
Map 2. Se in the $5^{\text {th }} \mathrm{pl}^{29}$

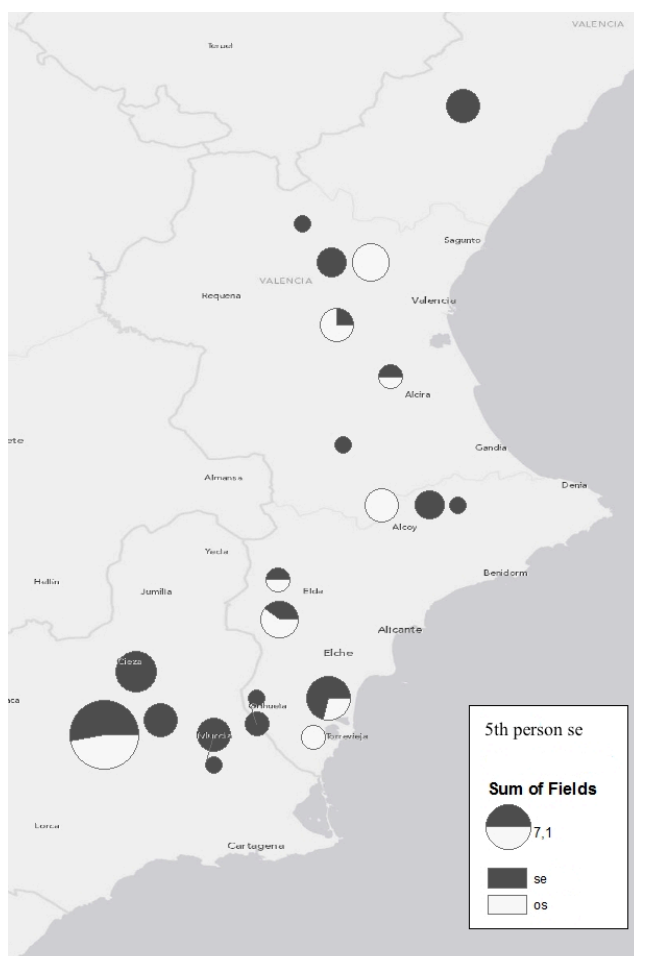

Map 3. Se in the $4^{\text {th }} \mathrm{pl}$

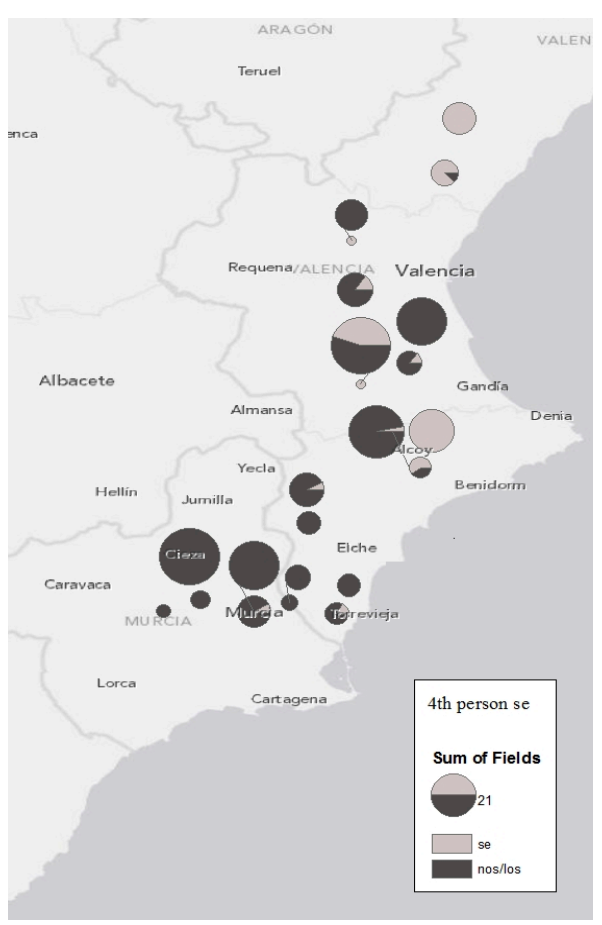

Such an evolution seems especially plausible in Eastern Spanish, where another syncretism in the pronominal paradigm is attested. In a bigger area, but that also includes the Valencian Country and Murcia, the non-reflexive masculine plural accusative clitic (los) can be used also as the $4^{\text {th }}$ and $5^{\text {th }}$ object clitic (both reflexive and non-reflexive) ${ }^{30}$, as shown in (17) (Enrique-Arias 2011).

\section{Pronominal paradigm in Eastern Spanish}

\begin{tabular}{|l|l|l|l|}
\hline & $1^{\text {st }}$ person & $2^{\text {nd }}$ person & $3^{\text {rd }}$ person \\
\hline singular & me & te & lo/la/le \\
\hline plural & nos/los & os $/$ los & los $/$ las $/$ les \\
\hline
\end{tabular}

By studying the geographical extension of the phenomenon, Enrique-Arias (2011) has shown quite convincingly that this syncretism started in the $5^{\text {th }}$ person and spread later to the $4^{\text {th }}$ : all the villages with los in the 4 th also have the syncretism in the 5th, while the opposite is not true. It seems likely, then, that if a new syncretism in the

29 The dots in maps 2 and 3 are pie charts illustrating the proportion between se and other forms in each interview (in raw numbers). Its size varies according to the total number of examples found in each interview. An indication of the equivalence between size and number of examples is given in the legend under the title "sum of fields".

The existence of such a syncretism is also an important counterexample to Benincà \& Poletto's claim "that Kayne's hypothesis concerning the fact that $s+\mathrm{V}$ is in a single paradigm with the $m, t, n, v+\mathrm{V}$ forms, while $l+$ agreement is excluded from it, is confirmed by the fact that the extensions found in Romance languages involve the $s+\mathrm{V}$ form frequently substituting for the $m, t, n, v+\mathrm{V}$ forms, but never for the $1+\mathrm{V}$ forms" (Benincà \& Poletto 2005: 269). 
pronominal system were to be born within this area, it would follow the same person hierarchy, which was already operative in their system. ${ }^{31}$

From a diasystematic point of view, several pronominal systems can be identified in the area under study: 1) the standard system, with different pronouns for every person and a distinct reflexive pronoun for the $3^{\text {rd }} / 6^{\text {th }}$ person; 2) the system described by Enrique-Arias, with a single pronoun in the $4^{\text {th }}$ and $5^{\text {th }}$ persons, common to one of the $6^{\text {th }}$ person forms - and a distinct reflexive pronoun for the $3^{\text {rd }} / 6^{\text {th }}$ person, and 3 ) the system I am analysing here, that grammaticalises the difference between reflexive and non-reflexive pronouns in the plural. Some speakers used all the three different possibilities in a single interview, using, for example, nos, los and $s e$ for the $4^{\text {th }}$ person reflexive (but only nos and los for the $4^{\text {th }}$ person non-reflexive).

An evolution such as $3^{\text {rd }} / 6^{\text {th }}>5^{\text {th }}>4^{\text {th }}$ can be readily explained if we take into account a dialectal phenomenon that could have acted as the main bridging context (Heine 2002) for the spread of se to the $5^{\text {th }}$ person in the first place. In most varieties of Peninsular Spanish, the imperative is syncretic with the infinitive. ${ }^{32}$ That is to say, in most varieties of Peninsular Spanish the original imperative form in $/-\mathrm{d} /$ has been replaced by the infinitive form in /-r/ (cf. Fernández-Ordóñez (2012) for a study of the geographical distribution of this syncretism). Crucially, in some varieties, this infinitive pro imperative takes a $3^{\text {rd }}$ person reflexive pronoun, as shown by the ALPI data, in map 4. Although this feature is a stereotype of Southern (Andalusian) varieties, the data from the ALPI shows that it has quite a larger extension, including our area of interest. According to these data, the use of se in the infinitive pro imperative is especially common in Andalusia, in a small but compact area to the South of Madrid and in Murcia and the Valencian Country.

31 Although slightly different, two other dialectal phenomena come to mind. First, the levelling of the oblique pronominal paradigm after a preposition, which is also typical of Eastern Spanish, is both more frequent and more widespread in the $2^{\text {nd }}$ person than in the $1^{\text {st. }}$ para tu' 'for you.SG.NOM' > para yo 'for I' (Pato 2012). In these cases, the nominative forms tú 'you. SG.NOM' and yo 'I' are used after some prepositions instead of the oblique forms $t i$ 'you.SG.OBL' and $m i$ 'me.SG.OBL'. The result is a more regular pronominal system, since in all the other persons the nominative and the oblique are syncretic. Second, the regularization of the clitic linearisation in the combinations of a dative clitic + $s e$ is also more frequent and more widespread in the $2^{\text {nd }}$ person than in the $1^{\text {st }}$. That is to say, the vernacular forms te se and me se, used instead of the standard orders se me (se me cayó '3.REFL me.DAT fell.down') and se te (se te cayó '3.REFL you.DAT fell.down'), are quite common in the Peninsula, but the vernacular order is significantly more spread in the $2^{\text {nd }}$ person than in the $1^{\text {st }}$ (Heap 2003). The vernacular forms also imply a regularisation, since $s e$ is the only $3^{\text {rd }}$ person pronoun that may appear in the first position in combinations of clitics in Standard Spanish (Martín Zorraquino 1979). All these dialectal phenomena, then, emerge earlier in the $2^{\text {nd }}$ person than in the $1^{\text {st }}$, although the latter would be the only example where the singular preceded the plural in the regularisation (nos se and os se, although existent, are quite rare).

As said above, in America the $5^{\text {th }}$ person nominative pronoun vosotros/as has been replaced by the formal $6^{\text {th }}$ person form ustedes, so the plural imperative takes the $6^{\text {th }}$ person subjunctive form. 
Map 4. Imperatives in the $A L P I^{33}$

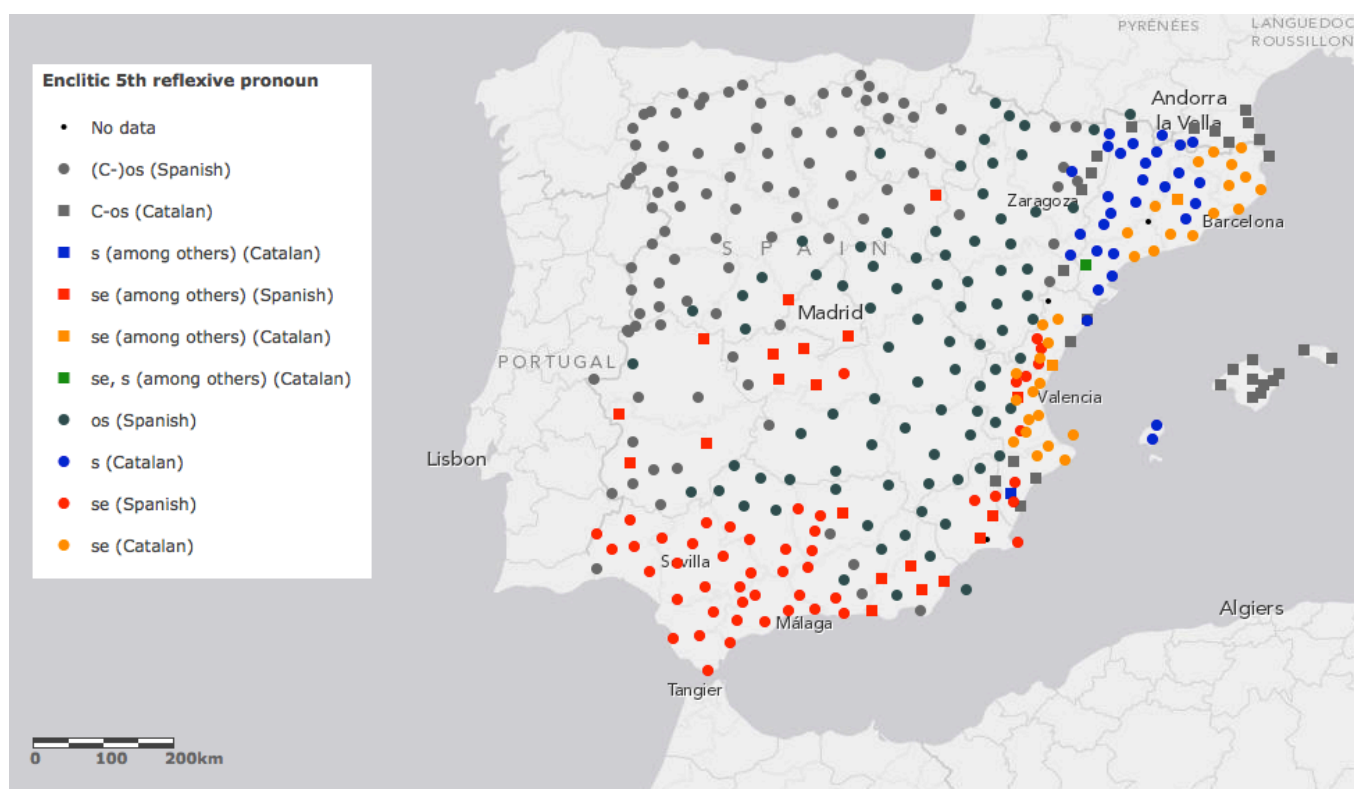

That is to say, the apparent mismatch between the $5^{\text {th }}$ person in the imperative and the $3^{\text {rd }}$ in the reflexive is most likely explained by the fact that the imperative takes the form of the infinitive. Infinitives, being non-finite forms, take $3^{\text {rd }}$ person reflexive clitics as the default form with arbitrary, indefinite or generic subjects, for example. According to this hypothesis, this association of the infinitive and $s e$ would trigger the appearance of se together with the infinitive in other contexts, like the imperative. Why the imperative and not other controlled infinitives? Two reasons can be suggested. On the one hand, the imperative use would be the only one where infinitives have a controlled subject that can be (and normally is) absent in the clause, which makes the mismatch less salient: (18a) vs. (18b). On the other hand, in some contexts imperatives are semantically similar to generic instructions, which take $3^{\text {rd }}$ person reflexive clitics $(18 \mathrm{c}){ }^{34}$
a. ¡Callarse
de una vez! / ¡Callaros
de una vez!
Shut.up.INF-3REFL of one time Shut.INF-2PL.ACC of one time
'Shut up once and for all!'
b. ¿Queréis callarse?
Want.2PL shut.up.INF-3REFL
'Would you shut up?'
/ ¿Queréis callaros?
Want.2pl shut.up.INF-2PL.ACC

(Spanish)

The map corresponds to questions 344, ;Arrodillaos! (Kneel.2PL-2PL.REFL down!), and 345 , Bebeos este vaso de aguardiente (Drink.2PL-2PL.REFL that glass of liquor). The solutions in grey, labelled as $C$-os, include the varied substandard forms that the $5^{\text {th }}$ person pronoun os may take, all preceded by a consonant (los, sos, tos). The ALPI does not attest the solution seos, which was found in the COSER interviews. To figure out whether this form comes from a doubled pair se + os similar to those attested in some Lombard varieties (although seos is not restricted to reflexive contexts) or it has a different origin is beyond the goals of this paper.

Interestingly, in Sacile (Friulian), se is already used in the $4^{\text {th }}$ person, but in the $5^{\text {th }}$ is restricted to imperatives, although in this variety there is no imperative-infinitive syncretism (Benincà \& Poletto 2005). 
c. A callarse de una vez.

To shut.up-3REFL of one time

'Now (let's) shut up'

The quantitative COSER data (see table 2), although confirming the relevance of the infinitive, seem to suggest that the infinitives that most favour the appearance of se are the non-imperative ones $(93,31 \%)$. The few data in some of the slots, however, precludes us from taking statistical significance tests, which would not offer any garanties, so more data would be welcome to check if there are some significant differences between the two types of infinitives. On the other hand, the difference between infinitives and finite forms $^{35}$ is statistically significant $(0.01887)$ and suggests that the syncretic pronoun is more frequent with the former. Nevertheless, in this particular case the infinitives coincide with enclitic environments and the finite forms with proclitic contexts, so there is no way of telling which factor is the determining one. ${ }^{36}$

Table 2. $5^{\text {th }}$ person clitic in the COSER data

\begin{tabular}{|c|c|c|c|c|c|}
\hline & \multicolumn{3}{|c|}{ Enclitic (infinitives) } & \multirow{2}{*}{$\begin{array}{l}\text { Proclitic } \\
\text { (finite } \\
\text { forms) }\end{array}$} & \multirow[b]{2}{*}{ Total } \\
\hline & $\begin{array}{l}\text { Infinitive pro } \\
\text { imperative }\end{array}$ & $\begin{array}{l}\text { Not } \\
\text { imperative }\end{array}$ & Subtotal & & \\
\hline se & 15 & 12 & 27 & 23 & 50 \\
\hline se\% & $71.43 \%$ & $92.31 \%$ & $79.41 \%$ & $51.11 \%$ & $63.29 \%$ \\
\hline$(\mathrm{C}-)$ os & 6 & 1 & 7 & 22 & 29 \\
\hline$(\mathrm{C}-) \operatorname{os} \%$ & $28.57 \%$ & $7.69 \%$ & $20.59 \%$ & $48.89 \%$ & $36.71 \%$ \\
\hline Total & 21 & 13 & 34 & 45 & 79 \\
\hline
\end{tabular}

$\mathrm{p}=0.01887(<0,05)$

Unfortunately, the ALPI does not offer any examples of a $5^{\text {th }}$ person sentence with a reflexive verb in the infinitive other than the imperative ones, a geographical distribution that could have revealed the differences between the two uses of infinitives. Some COSER examples are given in (19).

COSER

a. Cuando vais a venir, Puri, pa estar-se dos o tres días?

(Spanish)

(Palacios Blancos, MU 3111)

when go.2PL to come Puri to stay.INF-3REFL two or three days

'Puri, when are you going to come and stay two or three days?'

35 Enclisis is restricted in Spanish to non-finite forms and the imperative, but no gerunds or imperatives in $-d$ appeared in our $5^{\text {th }}$ person data set, so all the examples are infinitives.

36 In the los syncretism the position of the clitic is also a relevant factor, although in the opposite direction: los (the syncretic and new form) is quite more often a proclitic than an enclitic. Enrique-Arias (2011) proposes that this is an indication of its phonetic origin, for the $5^{\text {th }}$ person pronoun is the only one beginning with a vowel. 
b. Si encontrabas una persona y te gustaba (Lucena del Cid, CA 1308) if found.2sg a person and you.DAT liked.3sG 'If you found someone you liked'

y se aveníais hablando los dos, pues ibais acudiendo and 3.REFL got.along.2PL talking the two well went.2PL going 'and you both got along, then you started going' los domingos normalmente, a juntar-se [...] the sundays normally to get.together.INF -3REFL 'normally on Sundays to meet [...]'

The ALPI, however, contains two other questions where the distribution of proclitic $5^{\text {th }}$ person $s e$ (see COSER examples in (20)) can be traced. Map 5 shows the answers to the questions 341, Os vais a caer (2PL.ACC go.2PL to fall.dawn 'You guys are going to fall down') and 343, ¿Os queréis callar? (2PL.ACC want.2PL shut.up 'Would you guys shut up?'). ${ }^{37}$

(20) COSER

a. [el libro] Se lo lleváis. Pero vosotros le (Pedralba, VA 4318) [the book] 3.REFL it.ACC take.2PL but you.PL it.DAT

'Take it with you guys. You'

vais a sacar partido a cosas de antiguas ye lo lleváis. go.2PL to take.out game to things of old and 3.REFL it.ACC take.2PL 'are going to benefit from things of the elderly, so take it with you guys'

b. Pero se montáis, but 3.REFL go.up.2PL

'But go in,' pos montar-os en el coche, ir-os well go.up.INF-2PL.ACC in the car go.INF-2PL.ACC 'get into the car, leave'

c. Tú ve allí en Formentera, si You.SG go.IMP there in Formentera if 'Go there, to Formentera, if también se vais, hay un bar que le dicen El Pantano [...]' too 3.REFL go.2PL there.is a bar that it.DAT say.3PL the marsh 'you also go there, there is a bar called "The marsh" [...]'

As can be seen, map 5 shows a radically different picture. Proclitic $5^{\text {th }}$ person se seems to be confined to Western Andalusia and to a few points in Murcia and the Valencian Country. On the one hand, this map proves that the Western Andalusian $5^{\text {th }}$ person se and the Eastern Spanish one have developed independently, since it is unattested in Eastern Andalusia in proclitic contexts. ${ }^{38}$ On the other hand, the map shows a lower frequency of se in proclitic environments in Murcia and the Valencian Country. Although the significant visual difference between map 4 and map 5 is due to

$37 \quad$ These two questions could have actually been ideal for showing examples of enclitic se in a non-imperative context, since the reflexive verb appears in an infinitive periphrasis. However, the clitic appears in the first position, before the inflected verb, i.e. both of them are instances of the so-called clitic climbing.

Independently, but most likely from a common contextual usage (infinitive pro imperatives), as suggested by the continuous geographical distribution found along the Southern and Eastern coast in map 4. 
the fact that neither caure (Cat. 'fall down') nor callar (Cat. 'shut up') are reflexive in most of the Catalan speaking area, there is indeed a lower frequency of se in proclitic environments in the Spanish speaking area of the Valencian Country and in Murcia. Out of the 14 enclaves that had enclitic se in that area, only 7 had also proclitic se, 4 of which vary between $s e$ and $o s$, los or sos.

\section{Map 5. Proclitic se in the ALPI}

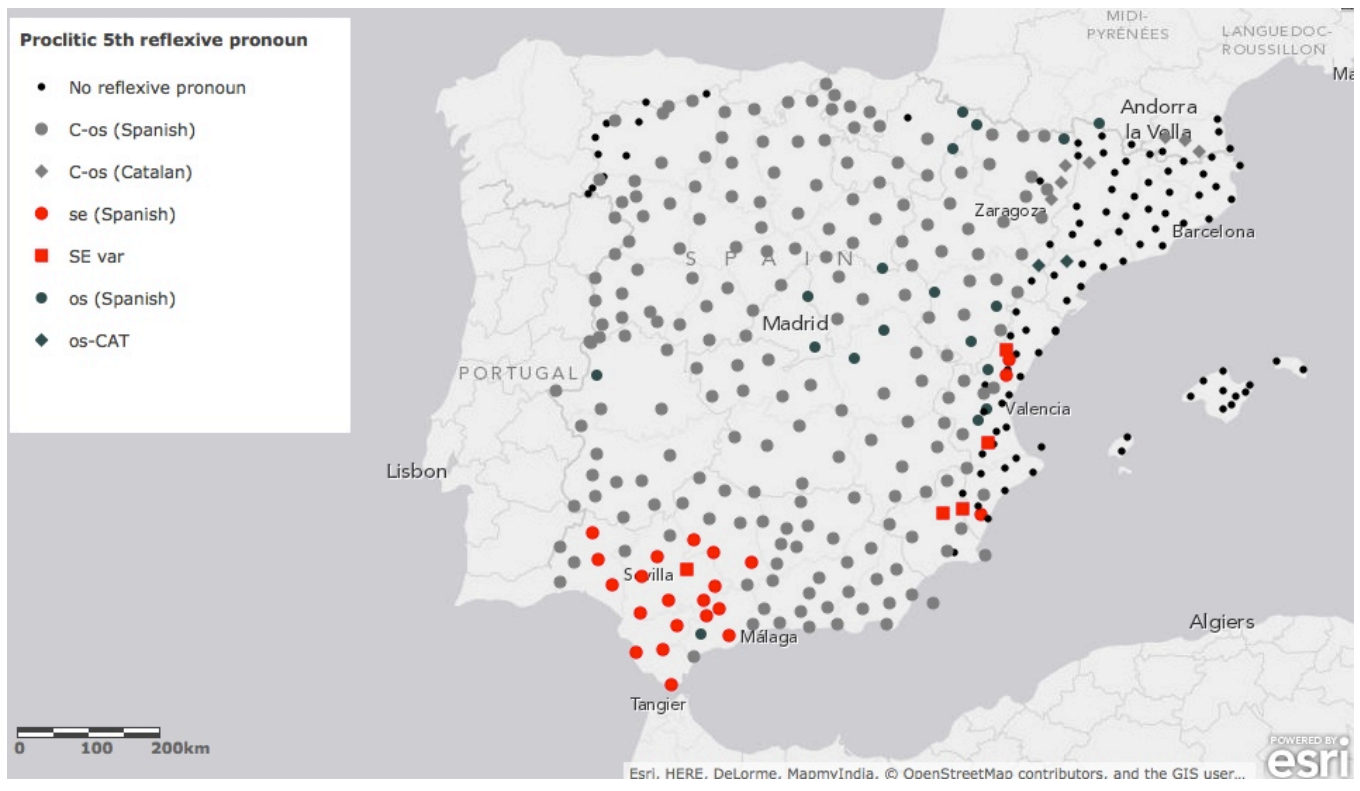

As mentioned above, in Western Andalusia this phenomenon is related to the loss of the $2^{\text {nd }}$ plural stressed pronoun vosotros and its replacement by the polite plural pronoun ustedes, which in principle requires $6^{\text {th }}$ person agreement. In Western Andalusia, however, the generalisation of ustedes in the $5^{\text {th }}$ person did not trigger automatic $6^{\text {th }}$ person agreement in these forms, which seems to be more developed in the pronominal system than in the verbal system (Lara Bermejo 2012). The agreement in the $6^{\text {th }}$ person is most widespread in the reflexive pronoun, followed by the nonreflexive pronouns and the verbal affixes. In Murcia and Alacant (and in Catalan) there is no such thing as the replacement of vosotros by ustedes, which means that the ALPI examples are unequivocal $5^{\text {th }}$ person reflexives.

Coming to the $4^{\text {th }}$ person se, the ALPI does not contribute any questions with reflexive verbs in that person. Some COSER examples can be seen in (21). Table 3 shows the COSER data according to whether the verb is an infinitive or not. ${ }^{39}$ The high $p$ value (0.8179) of these data clearly shows that its distribution is most likely due to chance and that this is not a relevant factor for the $4^{\text {th }}$ person, despite its importance in the $5^{\text {th }}$-although collecting more data may change the picture, since once again we find important differences between the two possibilities. gerunds (both with the non-syncretic form nos). Testing for the difference between enclisis/proclisis does not offer significant results either. 
(21) COSER

a. Cuando veías un mortero que te caía when saw.2sG a mortar that you.DAT fell 'When you saw a mortar that fell down' cerca de ti, éramos pequeños, pero se escondíamos como las ratas close of you were.1PL little but 3.REF hid.1PL like the rats 'close to you, we were children, but we hid like rats'

(Spanish)

b. Sí, se fuimos por la mañana (Palacios Blancos I2, MU 3111) Yes, 3.REFL went.1PL by the morning

'Yes, we left in the morning'

y volvimos por la noche and returned.1PL by the night 'and returned at night'

c. La cuestión que bajamos bajo pa despedir-se (Benimarfull, AL 303) The thing that go.down.1PL down to say.goodbye.INF-3REFL

'The thing is that we go down to say goodbye'

d. Y nosotros no pudimos comprar-se persianas

(Turís, Val 4324) And we not could.1PL buy.INF-3REFL shutters

'And we couldn't buy shutters'

Table $3.4^{\text {th }}$ person clitic in the COSER data ${ }^{40}$

\begin{tabular}{l|rrr|} 
1pl & Non-infinitives & Infinitives & Total \\
\hline Se & 60 & 9 & 69 \\
se $\%$ & $33.15 \%$ & $34.62 \%$ & $33.33 \%$ \\
nos $/$ los & 121 & 17 & 138 \\
nos $/$ los $\%$ & $66.85 \%$ & $65.38 \%$ & $66.67 \%$ \\
Total & 181 & 26 & 207
\end{tabular}

$\mathrm{p}=0.8179(>0,05)$

As for the causes of the spread of the syncretism to the $4^{\text {th }}$ person, internal pressure within the paradigm to regularise at least plural morphology seems to be an obvious call. However, there might be independent causes for this development (as the frequent $3^{\text {rd }} / 6^{\text {th }}>4^{\text {th }}$ developments in Northern Italian varieties already suggest) that should not be disregarded. $4^{\text {th }}$ person pronominal subjects or verbal morphology function as one of the impersonalising devices available in Spanish. As shown by the European Portuguese and the Eastern Spanish data in $(14,15)$ above, there is a connection between the reflexive marker, which marks impersonal sentences in many languages (all Romance languages, as a matter of fact), and the verbal morphology also used to mark impersonality $\left(6^{\text {th }}, 4^{\text {th }}\right.$ and $2^{\text {nd }}$ persons in Spanish), to the extent that both of them may appear as impersonal markers in one sentence.

But this connection also implies that these persons, when used as impersonal markers (hence intended as generic or indefinite), may trigger $3^{\text {rd }}$ person agreement, which is the default one for syntactically impersonal constructions. Examples in (22) illustrate quite nicely this bridging context between the $3^{\text {rd }}$ and the $4^{\text {th }}$ persons in Spanish. They were uttered by a speaker in Badajoz (Extremadura), in Central Western

40 In table 3 only data from villages with at least one example of the syncretism in the $4^{\text {th }}$ person are considered. 
Spain, where the syncretism has not been attested and the speaker did not show any other examples of it. They are most likely just some examples of the sporadic encounter of these two meanings in spoken discourse:

COSER, San Francisco de Olivenza, BA 726

(Spanish)

a. Ahora tenemos que preparar los pinchitos

Now have.1PL that prepare the snacks

'Now we have to prepare the snacks'

pa en cuanto los pidan dedicar-se a asar

for in as them.ACC ask.3PL devote.INF-3.REFL to roast

'so as to start roasting them as soon as they ask for them'

b. Las vacas..., los cerdos pa casa y las yeguas que nos dio

The cows the pigs for house and the mares that us.DAt gave.3sG

'The cows..., the pigs for the homes and the mares the institute'

el instituto pa poder ir gobernándo-se algo,

the institute to can.INF go.INF governing-3.REFL something

'gave us so we could manage somehow,'

aunque luego se llevaban su tanto por ciento

although after 3.REFL took.3PL their something per cent

'although they took a percentage afterwards'

Interestingly enough, there were two examples of $2^{\text {nd }}$ person $s e$ in the COSER interviews and both of them appeared in impersonal uses of this person (23). Since I did not recollect all the $2^{\text {nd }}$ person reflexive verbs, I cannot give quantitative data as to how frequent or rare they are compared to the standard $2^{\text {nd }}$ person $t e$.

COSER

(Spanish)

a. Uh, porque el tío, tú te casa-... (La Romaneta, AL 308)

Oh because the guy you.NOM you.REFL marry

'Oh, because the guy, you got marri-...,'

antes de casar-se tú, con tu mujer o con tu novia,

before of marry.INF-3.REFL you with your woman or with your girlfriend

'before you got married, with your wife or your girlfriend,'

tenía que casar-se él

had.3SG that marry.INF-3.REFL he

'he had to get married'

b. L' has de sacar de las hojas, el maíz,

it.ACC have.2SG of remove.INF of the leaves the corn

'You have to remove it from the leaves, the corn,'

para llevar-se el maíz

to take.INF-3.REFL the corn

'to get the corn'

To conclude this subsection, I should add that one example of $s e$ in the $1^{\text {st }}$ person was also found. It is given in (24). Quite interestingly, it was found in one of two speakers that showed a regular use of se in all the plural persons (although he did not show such a regular use in the $1^{\text {st }}$ person, as can also be appreciated in our example). It is also worth noting that all the examples in (23) and in (24) appear in infinitive contexts, reinforcing the idea of the close link between the se syncretism and this verbal form. 
(24) COSER, Benimarfull, AL 30

Si veía la, la, la pelea, yo me iba corriendo

(Spanish)

If saw.1SG the the the fight I me.REFL went.1SG running

'If I saw the, the, the fight, I went home'

a casa, yo no quería es..., yo quería reír-se, reir-se

to home I not wanted.1SG is I wanted.1SG laugh.INF-3.REFL laugh.INF-3.REFL 'immediately, I didn't want to..., I wanted to laugh, laugh.'

Before considering the influence of contact, put forward by Nebot Calpe (1984) and Blas Arroyo et al. (1992), I will take a look at the situation in Catalan in the next subsection.

\subsection{The reflexive syncretism in Catalan}

In Standard Catalan, the phonetic realization of object pronouns varies according to their position with respect to the verb and the phonetic environment, as shown in (25).

(25) Reflexive clitics in Catalan (adapted from Colomina i Castanyer 2002)

\begin{tabular}{|l|l|l|l|l|}
\hline & \multicolumn{2}{l|}{ Proclitic } & \multicolumn{2}{l|}{ Enclitic } \\
\hline & $+\mathrm{C}$ & $+\mathrm{V}$ & $\mathrm{C}+$ & V + \\
\hline 4th & ens & ens & nos & 'ns \\
\hline 5 th & us & us & vos & us \\
\hline 6th & es & s' & se & 's \\
\hline
\end{tabular}

However, the dialectal situation is (even) more complex. According to Perea (2012), reduced realizations of the $4^{\text {th }}$ and $5^{\text {th }}$ clitics nos/ens and vos/us as $s$ (or $z$ ) or, with a support vowel, se, are frequently found in both positions. That is to say, in Catalan, phonetic reasons may cause the syncretism between the $3^{\text {rd }}$ person reflexive pronoun and the $4^{\text {th }}$ and $5^{\text {th }}$ pronoun in many varieties. That this phenomenon is caused by phonetic reasons is corroborated by the fact that the syncretism can be found in nonreflexive clitics: ${ }^{41}$

41 Strangely, on the map SIN-79 of the Linguistic Atlas of Castile-La Mancha (ALECMan, García Mouton and Moreno Fernández 1988), which charts the nonreflexive $5^{\text {th }}$ person pronoun in the sentence $O$ s dieron dinero (you.PL.DAT gave.3PL money 'They gave you guys money'), 5 points in Toledo offer se as a possible solution (these are La Calzada de Oropesa (TO 109), Talavera de la Reina (TO 301), Belvís de la Jara (TO 311), Ocaña (TO 410) and Yepes (TO 412)). These are quite surprising examples, since a phonetic reduction of sos, sus or $/ \mathrm{suh} /$ (the typical form that $o$ takes in Toledo) to $/ \mathrm{se} /$ is difficult to explain. Unfortunately, the ALECMan only gives the pronoun form and not the complete sentences nor how the question was asked, so it is impossible to know the exact context of occurrence (may the sentence have been interpreted as reciprocal by the informants?). Even more strangely, none of these villages used se in the reflexive infinitive pro imperative context charted in the map SIN-34, Sentaros vosotros en las sillas (sit.down.INF-2PL.ACC you.PL in the chairs 'Sit down in the chairs'), although some of the neighbouring villages did. Martín Zorraquino (1979: 361-2) documents se venís (3.REFL come.2SG 'you come') in Ocaña (Toledo), but it seems that the syncretism only appears in such a sentence. All this together indicates that we need more data in this area. Since it is disconnected from our Eastern Spanish area, I think the Toledo examples cannot suggest a phonetic origin for the syncretism as found in the Valencian Country and Murcia. 
(26) Alcover \& Moll (1968: 149)

a. Per acompanyà 's ha vingut

(Catalan)

(Camp

For accompany.INF.3.REFL has come.PTCP

'He has come to accompany us'
b. S' enviaràs el paquet
3.REFL send.FUT.2SG the pack
'You will send us the pack'
(Penedès, BAR)

However, although these data clearly prove that phonetic processes have originated the syncretism in Catalan, there is also evidence that suggests that these reduced forms were later reanalysed and that $4^{\text {th }}$ and $5^{\text {th }}$ person se in Catalan is most commonly felt as reflexive.

First, although the form ' $s / s$ ' can be easily described as a reduced form due to phonetic simplification processes $(u s>s$, ens $>s)$, the form $s e$ is harder to explain on phonetic grounds. Catalan accepts quite a number of final consonants and $/-\mathrm{s} /$ is definitely not a problematic one. As Perea (2011: 442) points out, this casts some doubts on the epenthetic origin of the vowel; I concur. I believe, however, that the vowel in se could be explained if we do not consider it a reduced form but the expression of the reflexive $3^{\text {rd }}$ person pronoun.

Second, the non-reflexive examples of the syncretism are quite rare and a vast majority of the examples found in the literature are reflexive. As mentioned already, the phenomenon is condemned in several Valencian grammars. Salvador (1974), Guinot i Galan (1987) and Fabra (1913-14) document the phenomenon without specifying if the replacement of ens and vos by se is restricted to reflexive contexts, but all the examples they give are reflexive.

Sanchis Guarner (1950: 231), a native Valencian speaker, actually specifies that the syncretism is found in reflexive contexts: "A la capital i a gran part de la Regió Valenciana, s'usa vulgarment el pronom reflexiu se a indicar també l'acció reflexiva de 1. a i 2. pers. plur. (nosatros es llavem; llavem-se; vosatros es llaveu, llaveu-se)". ${ }^{3}$ Bonet (1984: 138) agrees that the syncretism is excluded when there is no subject-object coreference and that it can only appear in reflexive contexts.

Perea (2012), as previously mentioned, considers the syncretism to be a phonetic phenomenon. She attests it (in the $5^{\text {th }}$ and in the $4^{\text {th }}$ persons) both in Alcover's material and in the COD questionnaire. ${ }^{44}$ However, all the examples she gives are either reflexive verbs or combinations of two clitics (see (27)). Alcover \& Moll (1968) consider that this $4^{\text {th }}$ and $5^{\text {th }}$ person se comes from an analogy with the reflexive pronoun, and they specifically claim that it has reflexive meaning in the $5^{\text {th }}$ person.

$42 \quad$ Maria Pilar Perea (p.c.) points out that the loss of the infinitive $-r$ in the periphrastic past when it is followed by a $3^{\text {rd }}$ person clitic may have some influence in these reduced forms, since in such cases the clitic attaches directly to a vowel and there is no epenthetic vowel involved: va animar-los (go.3SG encourage.INF them.ACC 'S/he encouraged them') $>$ va animà'ls.

"In the capital city and in a large part of the Valencian region, the reflexive pronoun se is vulgarly used to mark also the reflexive action in the $1^{\text {st }}$ and $2^{\text {nd }}$ person plural (we 3.REFL wash.1PL; wash.1PL-3.REFL; you.PL 3.REFL wash.2PL; wash.2PL-3.REFL)", my translation.

As said above, there were no instances of syncretism in the COD interviews. 
They, however, give a few non-reflexive examples in both persons, all of them in clitic clusters except for the two examples in (26). In all the works mentioning the phenomenon I have managed to review, those two are, actually, the only ones that do not present a reflexive meaning or are in a clitic cluster. In map 6 I have charted the geographical distribution of the reflexive examples compiled by Perea (2012) and Alcover \& Moll (1968), the two sources with more data. ${ }^{45}$

a. $C$ 'hu diré (Barberà de la Conca, TA, Perea 2012: 1053)

(Catalan)

3.REFL it.ACC tell.FUT.1SG

'I will tell you guys'

b. Ja $s$ 'en daré (Vilabertran, GI, Alcover \& Moll 1968: 149)

Yet 3.REFL it.PART give.FUT.1SG

'I will eventually give you of that'

Map 6. The syncretism in Catalan: Alcover's materials and the COD questionnaires



Although with these highly unsystematic data I do not dare propose a diachronic evolutionary path, a few details are interesting to note. On the one hand, map 4 (which charts the ALPI data for imperative sentences) already presents some data on the syncretism in Catalan. Most interestingly, the distribution of $s$ and se in map 4 is not the same. While the reduced $s$ form is found in Eastern Catalan; Western Catalan and Valencian prefer se. There is no such thing as the infinitive pro imperative in Catalan, which means that these examples are perfectly transparent $5^{\text {th }}$ person verbal forms: begueu-se/beveu-se ('drink.2PL-3.REFL'), agenolleu-se ('kneel.down.2PL-3.REFL'). Although Perea's and Alcover's data do not draw such a sharp division in map 7, map 8 does show some difference between Eastern Catalan on the one hand and Western Catalan and Valencian on the other as regards the syncretism in the $4^{\text {th }}$ person.

45 Only the examples with a specific geographic adscription are charted in map 6. That is, examples that were said to be general in a certain dialect or were taken from popular songs are not represented in the map. 
This difference may indicate that the $4^{\text {th }}$ person was also the last to come in Catalan, but the absence of quantitative data for Catalan precludes us from proposing a person hierarchy similar to the one suggested above for Spanish.

\section{Map 7. $5^{\text {th }}$ person syncretism in Catalan ${ }^{46}$}

Map 8. $4^{\text {th }}$ person syncretism in Catalan
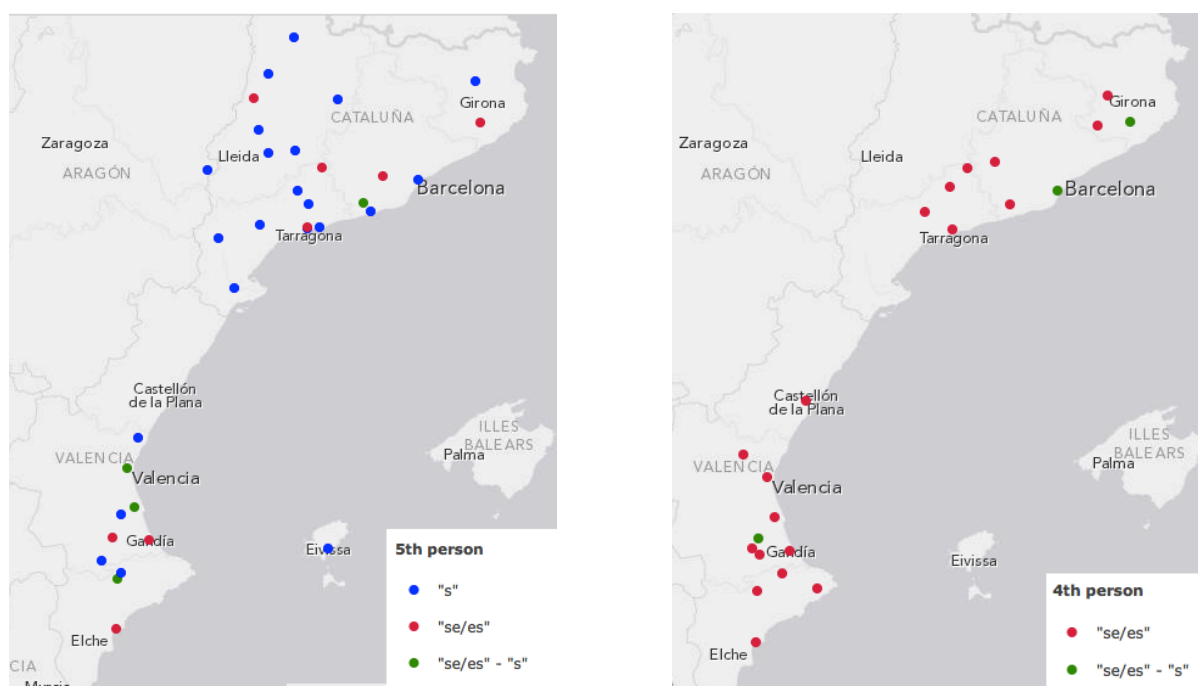

\subsection{What about contact?}

So far I have put forth some independent causes for the development of the reflexive syncretism in Catalan and Spanish. Does this mean that contact is to be ruled out as a possible explanation? Well, not necessarily. Since no linguistic change is necessary (and we cannot identify sufficient conditions for a change to happen, cf. Winter-Froemel (2013-14)), all possible (and plausible) causes are welcome when we are dealing with understanding and explaining linguistic variation and change. ${ }^{47}$ Indisputably, the fact that the syncretism is found in contiguous varieties of these two languages is not fortuitous. On the one hand, contact may help explain that, of all the area that presents "imperative (infinitive) $+s e$ " in Peninsular Spanish, only these varieties have extended the reflexive pronoun se to other persons and positions. This is not clear, however, since Murcia, an area with no modern significant contact with Catalan, also shows the syncretism (and already did at the beginning of the last century, as the ALPI data show). ${ }^{48}$ On the other

Maps 7 and 8 only chart the unequivocal examples of $s$ or $e s / s e$, hence excluding all the examples with the clitic en, that prevents us from deciding whether a reduced or a full form was used (cf. se n'anem, 3.REFL it.ABL go.1PL, 'we leave').

As for what concept of cause and explanation should we use in linguistics, cf. the discussion section in Energeia (2013-14) (especially Itkonen (2013-14), Willems (201314) and Winter-Froemel (2013-14)), most of which I subscribe.

Except for a rather small and isolated area (called Carxe) on the Western border with Alicante, where Valencian has been spoken since the late $18^{\text {th }}$ century (Sanchis Guarner 1950, 1973), Murcia has not been in contact with Catalan since the Middle Ages. The reduced size of this area and the low sociolinguistic prestige of its inhabitants make very implausible that a Catalan morpheme would have been borrowed into Murcian Spanish from this contact situation. To attribute this phenomenon to interference of Catalan in Murcia would then imply to date it back at least to the end of the $15^{\text {th }}$ century, when the last important contingent of Catalan-speaking repopulators arrived in the area, as a consequence of a bubonic plague. However, it is the period between the second half of the $13^{\text {th }}$ century and the beginning of the $14^{\text {th }}$ the period that is usually 
hand, it seems likely that the fact that $4^{\text {th }}$ person se in Spanish is restricted to the Valencian Country (and almost absent in Murcia) is due to contact with Catalan (which does not imply necessarily a calque - contact may have just been a catalyst), since in this language phonetic reasons can explain the syncretism in both persons and these do not show important differences concerning their geographical distribution. Contact with Spanish may, however, explain the specialization in the reflexive meaning of the Catalan phonetically driven solution. It is, definitely, hard to tell.

With or without contact, the ALPI data and the fact that the COSER attests the syncretism in the speech of both Catalan-Spanish bilinguals and Spanish monolinguals suggest that it has been around for at least some time. The following example (also an infinitive!), found in a 1808-1809 document signed by a "religious from the province of Valencia", ${ }^{49}$ probably from Comtat, is more than 120 years older than the data in the ALPI:

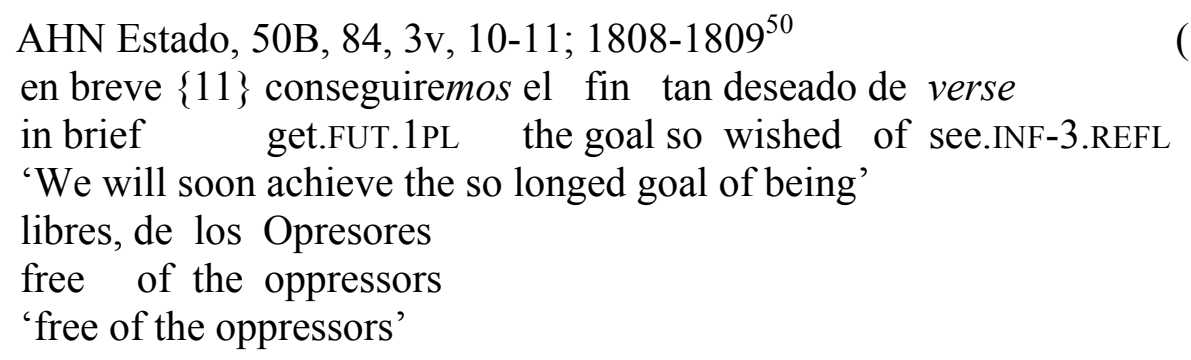

Although this is a single example (I have not performed any search in historical corpora), it looks like not only more dialectal data but also a historical study could enormously benefit our knowledge of the reflexive syncretism I have described here.

\section{Conclusion}

In this paper I have provided a first description of the extension of the reflexive se to all the plural persons in Eastern Spanish using dialectal data. I have proposed that this development started in the $5^{\text {th }}$ person and only later affected the $4^{\text {th }}$. I have also studied an analogous syncretism in Catalan and have tried to identify the possible causes for both developments.

From a more general point of view, I have connected this development (in both languages) to a typological tendency to mark all persons in reflexive contexts with the originally $3^{\text {rd }}$ person reflexive. The study of such a phenomenon in several Romance varieties has allowed me to cast some doubts on the scope of the person hierarchies previously proposed in the literature.

On the one hand, the person hierarchies proposed by Faltz (1985) and Benincà \& Poletto (2005) clearly do not hold. To begin with, they are in contradiction with each other. Faltz proposes that the $3^{\text {rd }}$ person marker spreads first to the $2^{\text {nd }}$ and then to the $1^{\text {st }}$

considered relevant to explain the significant lexical influence of Catalan in the Murcian Spanish dialect, when the Crown of Aragon sent a majority of (Catalan-speaking) repopulators to the area, although it already belonged to the Crown of Castile (see Sempere Martínez 1995). That would take the syncretism even further back, which is improbable due to the belated documentation.

49 Underlined in the original text.

50 I thank Álvaro Octavio de Toledo for generously providing me with this example, which comes from the DOLEO corpus, directed by Lola Pons and currently in preparation. 
(he does not consider number), while Benincà \& Poletto consider that, at least in Romance, the only possibility is $3^{\text {rd }} / 6^{\text {th }}>4^{\text {th }}>5^{\text {th }}>2^{\text {nd }}>1^{\text {st }}$. Puddu (2010) had already ruled out the possibility of finding a valid person hierarchy and the Romance data reviewed here suggest that both options are possible. As Puddu (2010) claimed, there is no universal person hierarchy governing the birth of the strategically streamlined reflexive paradigms.

On the other hand, Puddu's generalization (plural $>$ singular) seems to be much more robust and it is coherent with the fact that languages tend to show fewer distinctions in the plural than in the singular. ${ }^{51}$ Although in a few Northern Italian varieties the se syncretism had reached the $2^{\text {nd }}$ person before the $5^{\text {th }}$, this is definitely the least frequent situation in the varieties reviewed here. Puddu (2010) investigated quite a number of languages, so it may well be the case that the extension from plural to singular is the most frequent typologically.

When trying to establish a typological generalization, one should try to find either a functional or a cognitive explanation for it. But a close look to the reflexive syncretism in Romance languages suggests that there is not one, since all the possible origins of the extension of se are independent of its reflexive meaning. In Gallo-Italic and in Catalan, the most common origin of the extension adduced by scholars was phonetic processes. In Spanish, the syncretism between the imperative and the infinitive was probably the trigger of the reflexive syncretism. In Portuguese, the reorganisation of the subject pronominal paradigm and the consequent changes in agreement caused the pronominal paradigm to be highly syncretic. Language-particular quirks of history seemed to have played a crucial role in all these developments, so is it possible to propose typological generalizations?

Sometimes, typological studies observe the different phenomena from such a long distance that we may get the impression that languages are going somewhere on their own (as Castilho 1997 implied for Portuguese), but that is obviously not the case. The difference between functionally and strategically streamlined paradigms described by Faltz holds strongly cross-linguistically, so it most likely is functionally wellmotivated. Nevertheless, after looking at different languages showing the extension of the $3^{\text {rd }}$ person reflexive to the $4^{\text {th }}, 5^{\text {th }}$ and even $2^{\text {nd }}$ persons, I feel preliminarily inclined to deny that there is only one way of getting to the latter from the former. For all those different possibilities, I was able to find a possible semantic motivation, as shown above (section 4.1). This seems to indicate that the semantic side of the grammaticalization (functionally vs. strategically-streamlined reflexive paradigms) is independent of its formal side (the reflexive syncretism), and that is why it is difficult to find a universal tendency that brings them together (see Rodríguez Molina (2010), for an excellent elaboration of this idea regarding the evolution of Spanish perfects).

The study of Romance varieties allowed us to check for a few possible developments, but many others remain to be tested. Could we find a language where $3^{\text {rd }} / 6^{\text {th }}>2^{\text {nd }}$, skipping the previous $4^{\text {th }}$ step? Or should there always be a plural intermediate step? Can the $5^{\text {th }}$ person work as an intermediate step to the $2^{\text {nd }}$, skipping the $4^{\text {th }}\left(3^{\text {rd }} / 6^{\text {th }}>5^{\text {th }}>2^{\text {nd }}\right)$, since they both refer to the addressee? Is the $1^{\text {st }}$ person always the

$51 \quad$ For example, it is said that gender depends on number, meaning that languages never have more gender distinctions in the plural-or non-singular - than in the singular, as Greenberg proposed (Corbett 2000). As regards person, it is usually said that number depends on person (hence, the $3^{\text {rd }}$ person never has more number distinctions than the $2^{\text {nd }}$ and the $2^{\text {nd }}$ than the $\left.1^{\text {st }}\right)$. There are, however, examples of the opposite situation, where person depends on number, so the singular has more person distinctions than the plural, like in Hua (Gorokan) (Corbett 2000). 
last one to be affected by the syncretism? Can the syncretism develop from a person other than the $3^{\text {rd }} / 6^{\text {th }}$ ? I do not have answers to any of these questions. Only a thorough typological research could shed some light into them, most likely in terms of frequency.

\section{References}

Alcover, Antoni Maria and Francesc de Borja Moll. 1968. Diccionari Català-Valencià Balear. Barcelona: (Miramar) Moll.

Alves de Souza, Jurgen. 2011. As estruturas reflexivas no português afrobrasileiro.Master's thesis, Universidade Federal da Bahia.

ALPI. 1962. Atlas Lingüístico de la Península Ibérica. CSIC: Madrid. Available at: http://westernlinguistics.ca/alpi/

Badia i Margarit, Antoni Maria. 1962. Gramática catalana, vol. I. Madrid: Gredos.

de Benito Moreno, Carlota. 2010. "Las oraciones pasivas e impersonales con se: estudio sobre el ALPI". Dialectologia 5. Available at: http://www.publicacions.ub.es/revistes/dialectologia5/

Benincà, Paola and Cecilia Poletto. 2005. "The Third Dimension of Person Features". In L. Cornips \& K. P. Corrigan (eds.), Syntax and Variation. Reconciling the Biological and the Social, 265-299. Amsterdam/Philadelphia: John Benjamins. Available at: http://dx.doi.org/10.1075/cilt.265.15ben.

Blanchet, Philippe. 1992. Le provençal. Essai de description sociolinguistique et différentielle. Louvain-La-Neuve: Peeters.

Blas Arroyo, José Luis, Genoveva Boix Salvador, Enrique Gil Miguel \& Pedro Tejada Tello. 1992. Variedades del castellano en Castellón. Castelló: Biblioteca Popular, Diputació de Castelló.

Blas Arroyo, José Luis, Beatriz Navarro Morales, \& Juan Carlos Casañ Núñez. 2009. Corpus sociolingüístico de Castellón de la Plana y su área metropolitana. Castelló de la Plana: Publicacions de la Universitat Jaume I.

Bonet i Alsina, M. Eulàlia. 1984. Morphology after syntax: Pronominal Clitics in Catalan. Ph. D. Thesis. Boston (MA): MIT. Available at: http://www.ai.mit.edu/projects/dm/theses/bonet91.pdf

Carrera, Aitor. 2011. L'occità. Gramàtica i diccionari bàsics. Lleida: Pagès Editors.

Castilho, Ataliba Teixeira. 1997. "A gramaticalização". Estudos Linguísticos e Literários 19: 25-64.

Cole, Peter, Gabriella Hermon, Kim Chonghyuck, Sim Chang-Yong \& Tsai Yaping. 2003. "Anaphoric Expressions in Javanese". In A. Rakowski \& N. Richards. (eds.), Procceedings of AFLA VIII, 107-21. MIT Working Papers in Linguistics, 44.

Colomina i Castanyer, Jordi. 2002. "Paradigma flectius de les altres classes nominals". In J. Solà, M.-R. Lloret, M. Pérez Saldanya \& J. Mascaró (eds.), Gramàtica del Català Contemporani, 535-82. Barcelona: Empúries.

Corbett, Greville G. 2000. Number. Cambridge: Cambridge University Press. Available at: http://dx.doi.org/10.1017/cbo9781139164344.

Enrique-Arias, Andrés. 2011. "El sincretismo de persona en el plural (os, nos y los)". Lingüística Iberoamericana 43: 99-118.

Fabra, Pompeu. 1913-14. "Els mots àtons en el parlar de Barcelona". Butlletí de Dialectologia Catalana 1: 7-17.

Faltz, Leonard M. 1985. Reflexivization: A Study in Universal Syntax. New York: Garland.

Fernández-Ordóñez, Inés. 2012. "El norte peninsular y su papel en la historia de la lengua española". In S. Gómez Seibane \& C. Sinner (eds.), Estudios sobre tiempo y 
espacio en el español norteño, 23-68. San Millán de la Cogolla (La Rioja): CILENGUA.

Fernández-Ordóñez, Inés. 2005-. COSER. Corpus Oral y Sonoro del Español Rural. Available at: www.uam.es/coser

García Cotorruelo, Emilia. 1959. Estudio sobre el habla de Cartagena y su comarca. Madrid: Real Academia Española (Anejos del BRAE).

García Mouton, Pilar and Francisco Moreno Fernández. 1988. ALECMan. Atlas Lingüistico (y Etnográfico) de Castilla-La Mancha. Available at: http://www2.uah.es/alecman

Giacometti, Luigi. 2003. Elementi per una grammatica del dialetto Bregagliotto di Sopraporta. Thusis: Luigi Giacometti.

Guillén García, José. 1974. El habla de Orihuela. Alicante: Publicaciones del Instituto de Estudios Alicantinos.

Guinot i Galan, Josep $\mathrm{M}^{\mathrm{a}}$. 1987. Gramàtica normativa de la llengua valenciana. València: Lo rat penat.

Gómez Molina, José Ramón. 1986. Estudio sociolingüístico de la comunidad de habla de Sagunto (Valencia). València: Institució Alfons el Mangánim.

Heap, David. 2002. "Segunda noticia histórica del ALPI (a los cuarenta años de la publicación de su primer tomo)". Revista de Filología Española LXXXII (1-2): 519. Available at: http //dx.doi.org/10.3989/rfe.2002.v82.i1/2.141.

Heap, David. 2003. "Sentencias 'invertidas' de clíticos: un cambio (¿?) en tiempo real”. In J. L. Girón Alconchel \& J. J. Bustos Tovar (coords.), Actas del VI Congreso Internacional de Historia de la Lengua Española, 785-98. Madrid: Arco/Libros.

Heine, Bernd. 2002. "On the role of context in grammaticalization". In I. Wischer \& G. Diewald (eds.), New reflections on grammaticalization, 83-101. Amsterdam/Philadelphia: John Benjamins. Available at: http://dx.doi.org/10.1075/tsl.49.08hei

Herrity, Peter. 2000. Slovene: A Comprehensive Grammar. London/New York: Routledge.

Herzog, Eugen. 1914. Neufranzösische Dialekttexte. Leipzig: O. R. Reisland.

Itkonen, Esa. 2013-14. "On explanation in linguistics". Energeia V: 10-40. Available at: http://www.kabatek.de/energeia/

Kany, Charles. 1945. American-Spanish Syntax. Chicago: University of Chicago Press.

Lafone Quevedo, Samuel A. 1898. Tesoro de Catamarqueñismos. Buenos Aires: Pablo E. Coni e hijos.

Lara Bermejo, Víctor. 2012. "Ustedes instead of vosotros and vocês instead of vós: an analysis through the Linguistic Atlas of the Iberian Peninsula (ALPI)". Dialectologia III: 57-93. Available at: http://www.publicacions.ub.edu/revistes/dialectologiasp2012/

Martín Zorraquino, María Antonia. 1979. Las construcciones pronominales: paradigma y desviaciones. Madrid: Gredos.

Martins, Ana Maria. 2003. "Construções com se: mudança e variação no português europeu". In I. Castro \& I. Duarte (eds.), Razões e Emoção: Miscelânea de estudos em Homenagem a Maria Helena Mateus, vol. 2, 163-178. Lisboa: Imprensa Nacional - Casa da Moeda.

Meneghin, Claudi. 2008. "Rebuilding the Rhaeto-Cisalpine Written Language: Guidelines and Criteria. Part II. Morphology, I: Noun, Article and Personal Pronoun". Ianua. Revista Philologica Romanica 8: 113-52.

Meyer-Lübke, Wilhelm. 1906. Grammaire des langues romanes. Paris: Welter. 
Navarro Tomás, Tomás. 1975. "Noticia histórica del ALPI”. In T. Navarro Tomás, Capítulos de geográfia lingüística, 9-20. Bogotá: Instituto Caro y Cuervo.

Nebot Calpe, Natividad. 1984. "El castellano-aragonés en tierras valencianas (Alto Mijares, Alto Palencia, Serranía de Chelva, Enguera y la Canal de Navarrés)". Archivo de Filología Aragonesa XXXIV-XXXV: 395-535.

de Oliveira, Marilza. 2005. "Nós se cliticizou-se?" Ms. Available at: http://www.fflch.usp.br/dlcv/lport/pdf/maril014.pdf

Pato, Enrique. 2012. "Nivelación lingüística y simplificación: el uso de preposición $+t u ́$ en la historia de la lengua". In E. Montero Cartelle (ed.), Actas del VIII Congreso Internacional de Historia de la Lengua Española, vol. 1, 1029-39. Santiago de Compostela/AHLE: Meubook.

Perea, Maria-Pilar. 2011. "Els imperatius en contacte amb els enclítics pronominals". In R. Lloret \& C. Pons (eds.), Noves aproximacions a la fonologia i la morfologia del català, 427-457. Alacant: Institut Interuniversitari de Filologia Valenciana.

Perea, Maria-Pilar. 2012. "Els clítics pronominals preposats i posposats en català: anàlisi i comparació". In E. Casanova Herrero \& C. Calvo Rigual (coords.), Actas del XXVI Congreso Internacional de Lingüística y de Filología Románicas, vol. 2, 297-310. Berlin: De Gruyter. Available at: http://dx.doi.org/10.1515/9783110299915.297.

Perea, Maria-Pilar and Joaquim Viaplana. 2008. COD. Corpus Oral Dialectal. Selecció de textos. Available at: http://www.ub.edu/cccub/corpusoraldialectal-cod.html

PRESEEA. Proyecto para el estudio sociolingüístico del español de España y de América. Available at: http://preseea.linguas.net/Inicio.aspx

Puddu, Nicoletta. 2010. "Person in Reflexive Marking from an Integrated TypologicalHistorical Perspective". Presentation in the Workshop Variation and Change in Argument Realization, May 27th - 30th 2010, Napoli-Capri.

Quint, Nicolas. 1998. Le parler occitan alpin du Pays de Seyne. Paris/Montréal: L'Harmattan.

Quint, Nicolas. 1999. Le parler occitan alpin ardéchois d'Albon. Paris/Montréal: L'Harmattan.

Rodríguez Molina, Javier. 2010. La gramaticalización de los tiempos compuestos. PhD thesis, Universidad Autónoma de Madrid. Available at: https://repositorio.uam.es/xmlui/handle/10486/6279

Ronjat, Jules. 1937. Grammaire historique des parlers provençaux modernes. Montpellier: Société des Langues Romanes.

Salvador, Carles. 1974. Gramàtica valenciana. València: Climent.

Sanchis Guarner, Manuel. 1950. Gramàtica valenciana. València: Torre.

Sanchis Guarner, Manuel. 1973. "La frontera lingüística en las provincias de Alicante y Murcia". Cuadernos de Geografia 12: 15-29.

Sempere Martínez, Juan Antonio. 1995. Geografía lingüistica del murciano con relación al substrato catalán. Murcia: Real Academia Alfonso X el Sabio.

da Silveira, Larissa Marchi. 2008. "Quem Pariu Matheus Que Se Balance: Mais Tinta Sobre Os Clíticos No PB”. Anais do Seta 2: 501-507.

Stimm, Helmut. 1973. Medium Und Reflexivkonstruktion Im Surselvischen. München: C.H. Beck.

Vidal de Battini, Berta Elena. 1964. El español de la Argentina. Buenos Aires: Consejo Nacional de Educación.

Willems, Klaas. 2013. "Is frequency an explanatory causal concept in linguistics?". Energeia V: 105-112. Available at: http://www.kabatek.de/energeia/ 
Winter-Froemel, Esme. 2013-14. "What Does It Mean to Explain Language Change? Usage-Based Perspectives on Causal and Intentional Approaches to Linguistic Diachrony, or: On S-Curves, Invisible Hands, and Speaker Creativity". Energeia V: 123-142. Available at http://www.kabatek.de/energeia/ 